\title{
Competing for Securities Underwriting Mandates: Banking Relationships and Analyst Recommendations * *
}

\author{
Alexander Ljungqvist \\ Stern School of Business \\ New York University \\ and $C E P R$
}

\author{
Felicia Marston \\ McIntire School of Commerce \\ University of Virginia
}

\author{
William J. Wilhelm, Jr. \\ McIntire School of Commerce \\ University of Virginia \\ and \\ Saïd Business School \\ University of Oxford
}

July 14, 2003

\begin{abstract}
We investigate directly whether analyst behavior influenced the likelihood of banks winning underwriting mandates for a sample of 16,625 U.S. debt and equity offerings sold between December 1993 and June 2002. We control for the strength of the issuer's investment-banking relationships with potential competitors for the mandate, for prior lending relationships, and for the endogeneity of analyst behavior and the bank's decision to provide analyst coverage. Contrary to recent allegations, we find no evidence that aggressive analyst recommendations or recommendation upgrades increased a bank's probability of winning an underwriting mandate once we control for analysts' career concerns. In fact, the opposite appears to be the case. We interpret this finding as evidence that credibility is central to resolving information frictions associated with securities offerings. Overly aggressive analyst behavior undermines credibility. Differences across debt and equity sub-samples are consistent with this interpretation.

\footnotetext{
* We are grateful to Bill Greene for helpful suggestions, to Rajesh Aggarwal, Susan Chaplinsky, David Denis, Darrell Duffie, Greg Duffee, Ken Eades, Joel Hasbrouck, Florian Heider, Harrison Hong, Ajay Khorana, Robert Marquez, Jay Ritter, Gideon Saar, Tony Saunders, Daniel Wolfenzon, and Jeff Wurgler for useful thoughts, and to seminar audiences at Oxford University, the University of Virginia, New York University, the Oxford Summer Finance Symposium, and the 2003 Western Finance Association meetings for comments. We thank Thomson Financial I/B/E/S for making their analyst data available. All errors are our own.

${ }^{\dagger}$ Address for correspondence: Stern School of Business, New York University, Suite 9-190, 44 West Fourth Street, New York NY 10012-1126. Phone 212-998-0304. Fax 212-995-4233. e-mail aljungqv@ stern.nyu.edu.
} 


\title{
Competing for Securities Underwriting Mandates: Banking Relationships and Analyst Recommendations
}

\begin{abstract}
We investigate directly whether analyst behavior influenced the likelihood of banks winning underwriting mandates for a sample of 16,625 U.S. debt and equity offerings sold between December 1993 and June 2002. We control for the strength of the issuer's investment-banking relationships with potential competitors for the mandate, for prior lending relationships, and for the endogeneity of analyst behavior and the bank's decision to provide analyst coverage. Contrary to recent allegations, we find no evidence that aggressive analyst recommendations or recommendation upgrades increased a bank's probability of winning an underwriting mandate once we control for analysts' career concerns. In fact, the opposite appears to be the case. We interpret this finding as evidence that credibility is central to resolving information frictions associated with securities offerings. Overly aggressive analyst behavior undermines credibility. Differences across debt and equity sub-samples are consistent with this interpretation.
\end{abstract}

Key words: Analyst behavior; Underwriting; Commercial banks; Glass-Steagall Act.

JEL classification: G21, G24 


\section{Introduction}

The U.S. securities industry currently faces perhaps the strongest challenge to its integrity since the Great Depression. Particularly troubling are the allegations that investment bank research analysts systematically sacrificed objectivity, and thereby misled the investing public, to attract securities underwriting mandates for their banks. Recent work by Lin and McNichols (1998), Michaely and Womack (1999), and Bradley, Jordan, and Ritter (2003) lends weight to these allegations in the sense that analysts are shown to be more optimistic towards firms taken public by their bank.

Notwithstanding this correlation, there is no systematic evidence that analyst behavior influenced their bank's likelihood of attracting an underwriting mandate. ${ }^{1}$ Moreover, existing research focuses on initial public offerings of equity. While IPOs are the most lucrative segment of the securities underwriting business and sometimes mark the beginning of a banking relationship, they are a relatively small part of overall capital market activity. The bulk of this activity involves firms that are frequent participants in the capital markets, particularly for raising debt. Finally, the 1990s witnessed profound changes in the competitive landscape as commercial banks incrementally shed Glass-Steagall constraints on their ability to compete for securities underwriting mandates. By most accounts, commercial bank exploited their larger capital accounts to win underwriting mandates. Investment banks generally had smaller balance sheets but more reputation capital derived from their long experience with capital market transactions.

Against this background, we investigate directly whether analyst behavior influenced the likelihood of banks being awarded underwriting mandates for a sample of 16,625 U.S. debt and equity offerings sold between December 1993 and June 2002. Examining both debt and equity offerings enables us to compare settings (i.e., equity transactions) in which the intermediary's reputation capital is likely to be a central consideration for the issuing firm to those in which it is perhaps less important. Further, giving careful attention to a variety of strategic considerations facing both investment and commercial banks provides

\footnotetext{
${ }^{1}$ Recent work by Cliff and Denis (2002) suggests, however, that the probability of switching underwriters between the IPO and subsequent equity offerings is related to analyst behavior.
} 
considerable nuance to our understanding of the analyst's role in attracting underwriting mandates. Among other things, we suggest that it is useful to think of systematic deviations from objectivity in research as a means of trading on (or liquidating) one's reputation capital. We then explore whether such behavior was a competitive response to commercial bank entry during the sample period.

We find little evidence that analyst recommendation behavior influenced whether banks won equity mandates. In fact, aggressive recommendation behavior undermined banks' efforts to win equity mandates. This finding holds for both the early and latter parts of the sample period. Far more important appears to be the strength of the bank's relationship with the issuer as measured by the share of the issuer's past securities offerings (both debt and equity) underwritten by the bank, and to a somewhat lesser extent the strength of prior lending relationships. ${ }^{2}$ Examining the determinants of analyst recommendation behavior, we find evidence that more reputable analysts and banks were associated with less aggressively optimistic recommendations. We interpret these findings as a reflection of the prominent role of reputation in certifying quality for equity offerings (Chemmanur and Fulghieri (1994)) and the potential for overly aggressive analyst behavior to undermine a bank's credibility.

Frictions associated with asymmetric information are less severe for debt offerings. Other things equal, incentives to preserve reputation capital should then be less constraining for banks that specialize in debt underwriting, implying a greater willingness to test the limits of investor credulity. Less severe informational friction may also pose a weaker barrier to entry for potential competitors, a point that is borne out by the fact that commercial banks entered the securities underwriting business (and had their greatest competitive impact) in the debt markets. ${ }^{3}$ Consistent with this line of reasoning, we find some

\footnotetext{
${ }^{2}$ There is a substantial literature on commercial bank lending relationships (e.g., Boot and Thakor (2000), Diamond (1991), Petersen and Rajan $(1994,1995))$. There is much less theory to guide an empirical analysis of investment-banking relationships (but see Anand and Galetovic (2002)).

${ }^{3}$ Gande, Puri, and Saunders (1999) find that commercial bank entry is associated with a decline in debt underwriting spreads but not in equity underwriting spreads. The effect is strongest among lower-rated and smaller debt issues. Gande et al. (1997) provide evidence that commercial banks brought a larger proportion of small debt offerings to market during the January 1993March 1995 period and that more reputable banks (evidenced by market share) obtain lower yields for borrowers. Similarly, Livingston and Miller (2000) report slightly lower gross spreads and lower yields obtained by more reputable banks. After the first quarter of 1997, when the Federal Reserve Board relaxed constraints on cross-marketing and information flows between commercial banks and their "Section 20" affiliates, Roten and Mullineaux (2003) find little evidence that commercial banks and investment banks differed in their underwriting performance.
} 
evidence that analyst behavior favorably influenced banks' chances of winning debt mandates but only during the post-1997 period. Past underwriting and lending relationships remain a strong influence on the issuer's choice of bank but it appears that at least some banks were willing to provide aggressively optimistic recommendations in the hope of gaining competitive advantage in the debt markets.

In broad terms, we believe the evidence favors the interpretation that deregulation of commercial banks coupled with enormous deal flow in the late 1990s upset an equilibrium in which market forces (i.e., reputational concerns) moderated the longstanding conflict of interest between investment banking and research. Interpreting aggressive behavior among analysts (and its subsequent fallout) as liquidation of reputation capital, the evidence suggests that it did not serve banks' interests in the short term and we contend it is therefore not likely to characterize long-term equilibrium in the industry.

Our analysis is complicated by several factors. First, a favorable research report, though surely of value to a potential issuer, is not the only consideration in selecting an underwriter. In short, decisions at the transaction level are made within the context of banking relationships that are complex, vary through time, and are a relatively unexplored phenomenon. Among other things, Ljungqvist, Marston, and Wilhelm (2003) find evidence that bank research coverage decisions are strategic and heavily influenced by past dealings with the issuer. Second, a large literature documents systematic positive biases in earnings forecasts (Brown et al. (1985), Stickel (1990), Abarbanell (1991), Dreman and Barry (1995), Chopra (1998), and others). More recently, Hong and Kubik (2003) and Hong et al. (2000) provide evidence of career concerns in analyst forecast behavior. Analyst research is an experience good and thus individual analysts have incentive to build, and maintain, reputation for objectivity and forecast accuracy. The private incentive to protect one's reputation and the quasi rents it confers provide a countervailing force against incentives to sacrifice objectivity (Graham (1999)). In short, there is ample reason to believe that analyst behavior cannot be treated as an exogenous determinant of a bank's chances of winning an underwriting mandate.

We address these problems by empirically modeling the bank's coverage decision and analyst 
behavior under the assumption that each is embedded in a banking relationship that evolves over time. Their joint evolution, in turn, conditions the likelihood that an issuing firm grants an underwriting mandate to a particular bank. We develop this structural econometric model in Section 2. We use data from six principal sources (SDC, I/B/E/S, Dealscan, 13f filings, Institutional Investor magazine, and news reports) to estimate the model. Section 3 describes our data and coding choices in some detail. Our empirical results are in Section 4. Section 5 concludes.

\section{The Empirical Model ${ }^{4}$}

\subsection{Economic Structure of the Model}

In this section we outline the economic structure of the model and provide an overview of the key variables. We defer precise specification of the variables to subsequent sections.

Our central focus is on the determinants of a bank $j$ 's likelihood of receiving an issuing firm $i$ 's underwriting mandate at time $t$. The probability model takes the general form:

$$
\operatorname{Pr}(\text { bank } j \text { leads firm } i \text { 's deal at time } t)=f_{L}\left(\text { analyst behavior, } \mathbf{X}_{L}\right)
$$

where $\mathbf{X}_{L}$ is a matrix of explanatory variables. By "analyst behavior" we mean either the level of bank $j$ 's analyst's recommendation for firm $i$ 's stock, or the change in that recommendation. In either case, we normalize by the recommendation behavior of other banks. Thus, we test whether a bank is more likely to win an underwriting mandate if its analyst provided a relatively bullish recommendation for the issuer's stock, or recently upgraded the issuer's stock more aggressively than did other banks. We control for the reputation of the bank's analyst, the bank's research reputation, its broader reputation within the debt and equity markets, its lending capacity, and the strength of the bank's relationship with the issuer. Other things equal, we expect a higher probability of success from a more reputable bank that maintains a strong relationship with the issuer. Including proxies for lending relationships enables us to examine allegations that commercial banks successfully tied lending facilities to opportunities for underwriting capital market

\footnotetext{
${ }^{4}$ We are grateful to Bill Greene for helpful comments and advice on our empirical modeling strategy.
} 
transactions. Because we cannot observe the fees quoted by banks that subsequently fail to win an underwriting mandate, we do not attempt to control for price competition.

It is alleged that investment bankers pressured analysts to provide more favorable recommendations for potential issuers. However, research is an experience good so analysts have incentive to build and protect reputation for meaningful recommendations. Thus if analysts are self-interested, they should weigh career concerns against any immediate expected payoffs cooperation with investment bankers might bring. In short, treating analyst behavior as an exogenous determinant of the bank's probability of attracting an underwriting mandate is likely to bias inference. We address this problem by obtaining an instrumental variable for analyst behavior from the following model:

$$
\text { Analyst behavior at time } t=f_{A}\left(\mathbf{X}_{A}\right)
$$

where $\mathbf{X}_{A}$ is a matrix of explanatory variables that control for analyst reputation, bank reputation, timevariation in the size of the potential pool of "side payments" bankers might use to gain analyst cooperation, and the strength of the bank's relationship with the issuer. We envision the pool of potential side payments increasing with deal size and market-wide deal flow.

A bank's relationship with an issuer has potentially competing effects on analyst behavior. On the one hand, a bank and its analyst might sacrifice reputation capital to protect a rent stream associated with a strong relationship. Conversely, if an existing banking relationship presents a barrier to entry, there is less incentive for a reputable bank maintaining a strong relationship with the issuer to offer an aggressive recommendation. Competition via more aggressive analyst recommendations would then be the province of less reputable banks seeking to build relationships with issuing firms.

If every sample bank covered every sample issuer at the time of every sample transaction, we could estimate (1) and (2) as a system of two simultaneous equations with the dichotomous dependent variable in equation (1) the only non-standard feature (Maddala (1983), pp. 244-245). However, universal coverage is not a feature of the marketplace, and so we observe analyst behavior - and its effect on 
lead underwriter choice - only if bank $j$ covers firm $i$ 's stock at time $t$. Moreover, the selection criterion leading to this sample truncation is likely non-random: given resource scarcity it is plausible, and indeed likely, that bank research directors are strategic in their coverage decisions. We therefore model the coverage decision explicitly as follows:

$$
\operatorname{Pr}(\text { bank } j \text { covers firm } i \text { at time } t)=f_{C}\left(\mathbf{X}_{C}\right)
$$

where $\mathbf{X}_{C}$ is a matrix of explanatory variables that control for the strength of the bank's relationship with the issuer, the bank's reputation for research and its broader reputation, and various characteristics of the issuing firm that might attract coverage. Commercial banks were relatively late entrants to the equity markets and generally provided less equity research during the sample period. Thus we allow their coverage decision criteria to differ from those of investment banks.

\subsection{Econometric Structure of the Model}

If bank $j$ 's analyst covers firm $i$, we observe both the probability model for winning the underwriting mandate in equation (1) and the analyst behavior model in equation (2). Otherwise, we do not observe (2) and we observe only a modified form of (1) that relates the probability of winning the underwriting mandate to the explanatory variables $\mathbf{X}_{L}$ but not to analyst behavior. Suppressing subscripts for $i, j$, and $t$, the econometric model is:

\section{Coverage case:}

$$
\left.\begin{array}{l}
y_{A}=\beta_{A} \mathbf{X}_{A}+u_{A} \\
y_{L}^{*}=\beta_{L} \mathbf{X}_{L}+\delta_{L} y_{A}+u_{L}
\end{array}\right\} \quad \text { if } y_{C}^{*}>0
$$

\section{No-coverage case:}

$$
\left.\begin{array}{l}
y_{A}=0 \\
y_{L}^{*}=\beta_{L L} \mathbf{X}_{L}+u_{L L}
\end{array}\right\} \quad \text { if } y_{C}^{*} \leq 0
$$

where stars indicate unobserved latent variables whose realizations are observed as binary outcomes. Specifically, $y_{L}^{*}$ is a latent variable measuring the propensity of issuer $i$ to hire bank $j$ as lead 
underwriter, observed as $y_{L}=1$ if $y_{L}^{*}>0$ and $y_{L}=0$ if $y_{L}^{*} \leq 0 . y_{C}^{*}$ is a latent variable measuring bank $j$ 's propensity to cover firm $i$ 's stock at time $t$ which we observe with realizations

$$
\begin{array}{lll}
y_{C}=1 & \text { if } & y_{C}^{*}=\beta_{C} \mathbf{X}_{C}+u_{C}>0 \\
y_{C}=0 & \text { if } & y_{C}^{*} \leq 0
\end{array}
$$

$y_{A}$ is a continuous, observed variable measuring analyst behavior, and $u_{k}(k=L, A, C, L L)$ are error terms whose distributions are described shortly.

Although the $\mathbf{X}_{L}$ matrix in the two lead-bank equations in (4) and (5) remains the same, we do not constrain the two coefficient vectors $\beta_{L}$ and $\beta_{L L}$ to be equal. This enables us to test the hypothesis that in the absence of coverage and thus of strategic analyst behavior, prior relationships have a significantly stronger effect on the lead-bank hiring decision.

\subsection{Estimation}

Equations (4)-(6) form a simultaneous-equations system with endogenous switching (Maddala (1983), Ch. 8 and especially sections 8.3, 8.6 and Model 1 on p. 241). The switching criterion is given in (6), which determines whether we observe system (4) or (5). Estimation is carried out through the following two-step procedure. Consider first the coverage case $\left(y_{C}=1\right)$. In step 1, we estimate the determinants of analyst behavior, including all variables in $\mathbf{X}_{A}$ and $\mathbf{X}_{L}$. Since the model is recursive $-y_{L}^{*}$ depends on $y_{A}$ but not vice versa - it is not strictly necessary to include $\mathbf{X}_{L}$ when estimating the first-step equation. ${ }^{5}$ To ensure that the first-step estimates are consistent, we need to account for truncation due to non-coverage. Heckman (1979) shows that the errors in a truncated sample are not zero mean, and so OLS yields biased and inconsistent coefficient estimates. We therefore estimate the first-step coefficients using the MLE version of Heckman's sample selection correction using equation (6).

Step 2 estimates the determinants of a given bank winning a given underwriting mandate, replacing

\footnotetext{
${ }^{5}$ In principle, one could argue for simultaneity in the determination of $y_{L}^{*}$ and $y_{A}$ on the grounds that the analyst's expectation of the likelihood of her bank winning the mandate might influence her willingness to jeopardize her reputation by aggressively upgrading the issuer's stock recommendation. Empirically, we find a negative relation between $y_{A}$ and $E\left(y_{L}^{*}\right)$ but the relation is not statistically significant. We thus focus on the recursive model outlined here.
} 
the analyst behavior variable $y_{A}$ with the predicted values $\hat{y}_{A}$ from step 1 . Again, we account for truncation by adjusting the probit likelihood function for the sample selection bias, $E\left(u_{L} \mid y_{C}=1\right) \neq 0$ (see Van de Ven and Van Pragg (1981) for the derivation of the likelihood function). If the estimates from step 1 are consistent, and the equation system is identified, the second step yields consistent estimates for $\left(\hat{\beta}_{L}, \hat{\delta}_{L}\right)$. Since the second step involves a generated regressor (the predicted analyst behavior from the first step) estimated with sampling error, the second-step covariance matrix is not consistent. Consistent standard errors are obtained using the procedure derived in Murphy and Topel (1985, Section 5).

In the absence of coverage, $y_{A}=0$, and so we simply estimate a single-equation probit model, again corrected for truncation since $E\left(u_{L L} \mid y_{C}=0\right) \neq 0$.

Finally, because our unit of observation is a securities transaction, the model for the probability of a given bank winning an underwriting mandate conditions on information for both the winning bank and the banks that unsuccessfully competed for the mandate. Thus, for each transaction, we construct a data panel containing conditioning information for both winning and non-winning banks. To keep the estimation sample to a manageable size, we restrict the set of non-winning banks to those that were most "active" over the period as defined in the next section. Note that our probability model can be thought of as a generalization of the binary models that have been estimated to explain why some firms switch underwriters after their IPO (e.g. Krigman, Shaw, and Womack (2001)), in the sense that we allow firms not just to switch but to choose an underwriter from among our set of sample banks.

\section{Data}

\subsection{The Sample of Securities Offerings}

Between January 1, 1988 and June 30, 2002, Thomson Financial's Securities Data Corporation reports 36,173 debt and equity offerings, after excluding transactions by firms classified as SIC 6000-6999 (financial institutions etc) and SIC 9000-9999 (government agencies etc). The transactions or 'deals' range from IPOs to issues by seasoned firms, and include both public and private issues and issuing 
firms. We use the full sample period to generate a variety of variables, including prior relationships between issuers and banks. The distribution of different types of offerings is reported in Table 1. Public common stock offerings, public non-convertible debt and private non-convertible debt each account for around one third of the number of sample transactions but public debt dominates in dollar terms.

Many issuers are related to each other so we form "corporate families" on the basis of SDC's "ultimate parent CUSIP" identifier. This allows us to control for prior relationships between a given bank and any member of a corporate family. For example, AT\&T Corp is the parent of AT\&T Wireless, Vanguard Cellular Systems Inc, Lucent Technologies Inc, NCR UK Group Ltd, Teligent Inc, etc. Transactions involving any of these "subsidiaries" are grouped under AT\&T. Thus when Lucent went public in 1996, we condition the probability of a bank receiving the mandate on whether it had a relationship with any firm in the AT\&T family in the prior $T$ years. The 36,173 deals in 1988-2002 involve 15,306 unique firms reflecting 12,470 unique corporate families.

I/B/E/S data on analyst recommendations is available only from late 1993, so the estimation period for the econometric model includes a sub-sample of deals carried out between December 1, 1993 and June 30, 2002. We exclude a) any issuer or family of issuers which did not hire one of our sample banks (see below) for a capital raising transaction between 1988 and June 2002; and b) purely-foreign issuers or families of issuers (we do include corporate families that have at least one U.S. member). This leaves an estimation-period sample of 16,625 transactions, shown in the final two columns of Table 1, involving 6,821 unique firms and 5,472 unique corporate families.

\subsection{Sample Underwriters}

Estimating a bank's probability of winning the underwriting mandate for a particular offering requires data for both the winning bank and its competitors. We keep the size of the dataset manageable by focusing on the 16 most-active debt and equity lead (or co-lead) underwriters as measured by the nominal proceeds from deals completed during the $2000-2002$ period. ${ }^{6}$ Each bank is treated as a potential

\footnotetext{
${ }^{6}$ We exclude Bank One (whose debt market share places it above some of our sample banks) for lack of equity analysts.
} 
competitor for each deal in the estimation period (subject to regulatory constraints described below). Many of the sample banks are the product of mergers (or demergers) and acquisitions during the sample period, summarized in Figure 1. The predecessors of the 16 sample banks also are treated as potential competitors for a deal prior to joining forces with one of the final 16. For example, from the perspective of 1988, there were 41 independent sample banks in potential competition for each deal.

Table 2 reports summary statistics for the 16 banks to which we confine our attention. To compute the banks' market shares over the 1988-2002 period, we allocate to each bank the proceeds underwritten by its predecessor banks. For example, the $\$ 323$ billion in total capital underwritten assigned to JP Morgan Chase includes the underwriting mandates granted to JP Morgan, Chase, Chemical Bank, Hambrecht \& Quist, and Manufacturers Hanover during the sample period. The top five underwriters (Credit Suisse First Boston, Goldman, Merrill Lynch, Morgan Stanley, and Salomon Smith Barney) each held at least an $11 \%$ market share in the debt and equity markets, accounting in aggregate for $63.5 \%$ of the dollar amount of capital raised during the sample period.

Together, the 16 sample banks and their predecessors underwrote $\$ 1,181$ billion in equity and $\$ 2,524$ billion in debt (in nominal terms) over the sample period - more than $90 \%$ of underwriting activity in either market. Their combined market share ranged from $80.7 \%$ in 1988 to $96.4 \%$ in 1990 , falling below 90\% only twice, in 1988 and 1989. Excluding banks other than our final 16 and their predecessors therefore results in little loss of data but significant economies in coding banking relationships and in the probability model estimation.

The sample includes commercial banks whose ability to compete for public offers historically was restricted by the Glass-Steagall Act and regulatory rules. We account for this by treating a commercial bank as capable of competing for a public offering mandate prior to the repeal of the Glass-Steagall Act only if it had a so called "Section 20" subsidiary with Tier II securities underwriting authority granted by the Federal Reserve Board. ${ }^{7}$ Figure 1 documents the dates when sample commercial banks received such

\footnotetext{
${ }^{7}$ In some instances debt and equity approval were granted at different times.
} 
approval. Tier II authority was not required for private offers, so we treat every sample bank as being in competition for every private deal. On average, 24.3 banks competed for a given deal.

\subsection{Prior Investment-Banking Relationships}

The lag between the 1988 beginning of the sample period and the 1993 beginning of the estimation period provides us with at least five years of prior data for measuring investment-banking relationships. Our main proxy for the strength of an issuer's relationship with a particular bank focuses on the bank's share of the client's previous mandates, coded as follows. For firm $i$ at time $t$, we determine whether it (or any member of its corporate family) extended an underwriting mandate to bank $j$ or any of $j$ 's predecessors (but not $j$ 's successors). If so, we accumulate the proceeds from the deals that bank $j$ managed for firm $i$ in the preceding $T=1 \ldots 5$ years, and divide by the total raised by the firm to reduce the impact of differences in scale across firms. This measure ranges from zero (no relationship) to one (when the issuer maintained an exclusive banking relationship). It is computed separately for debt and equity deals, and for any sample bank that was a potential competitor for the underwriting mandate at time $t$.

In the simplest cases, such as Goldman Sachs, the implementation of the algorithm is straightforward. Cases involving one or more acquisitions are more complicated. Bank of America, easily the most complicated in the sample, illustrates the complexities involved. In October 1997, Bank of America acquired Robertson Stephens and, from our perspective, inherited Robertson Stephens' history of relationships with a particular firm $i$. Their joint history then conditions the probability of Bank of America winning any future mandate of firm $i$.

In June 1998, Robertson Stephens was sold to BankBoston (which was acquired by Fleet in 1999) in advance of Bank of America's September 1998 merging with NationsBanc. From this point forward, the mandate history of Robertson Stephens, including those received while owned by Bank of America, belongs to BankBoston (and then Fleet). But we also assume that the probability of Bank of America receiving a future mandate is conditional on the Robertson Stephens mandate history up to the time it was sold to BankBoston. This element of 'double-counting' reflects our inability to trace precisely the 
extent to which relationships remain exclusive to Robertson Stephens. ${ }^{8}$

Table 3 provides summary statistics for our relationship proxy at the maximum 5-year horizon used in our econometric model. (Our econometric results are somewhat stronger if we use shorter horizons, indicating that more 'recent' relationships carry more weight, but our qualitative conclusions are unaffected.) Results are reported separately for debt and equity transactions, and partitioned by whether or not the bank won the underwriting mandate and whether or not it provided research coverage for the issuer at the time of the deal in question. Banks providing research coverage that won equity mandates underwrote on average $47.4 \%$ of the issuer's equity proceeds raised during the prior five years. The strength of underwriting relationships appears less important among debt offerings as evidenced by the $26.2 \%$ share of debt proceeds underwritten by the average winner of an issuer's debt mandate. In general, winners of a mandate in a particular market (debt or equity) had stronger relationships with the issuer on both the debt and equity dimension.

\section{4 'Paying to Play'}

The more active firms in our sample (corporate families carrying out more than 20 transactions during the sample period) spread their transactions across 12.8 different lead underwriters on average (median: 12). This represents a marked decline in the exclusivity of banking relationships by comparison to earlier periods [Baker (1990), Eccles and Crane (1988)]. The decline of exclusive relationships can be traced in part to the weakening and ultimate repeal of the Glass-Steagall Act during the sample period. From the late 1980s the largest commercial banks bought or built first debt and then equity underwriting capacity in Section 20 subsidiaries. Throughout the early and mid 1990s the securities industry criticized commercial banks for using government-insured deposits to subsidize bids for underwriting mandates with offers of low-margin lending facilities. By 2001, 'paying to play' became commonplace as issuers in both the

\footnotetext{
${ }^{8}$ In June 1997 NationsBanc acquired Montgomery Securities. Thus in addition to "inheriting", relationships via its short-lived ownership of Robertson Stephens, Bank of America inherited relationships from Montgomery and NationsBanc at the time of the merger. On September 21, 1998, in the wake of the merger, Montgomery's founder, Thomas Weisel, resigned from Montgomery, founded Thomas Weisel Partners and subsequently raided a large fraction of Montgomery's banking professionals. Relationships held by Montgomery prior to Weisel's resignation are coded as being inherited by Weisel Partners, but similar to the "double-counting" in the Robertson Stephens case, we also count them as being held by Bank of America.
} 
public debt and equity markets demanded credit lines from banks bidding for underwriting business (Drucker and Puri (2002)).

We control for this change in the competitive landscape by constructing a measure of prior lending relationships similarly to the underwriting relationship measures outlined in the previous section. The underlying loan data are derived from the Loan Pricing Corporation's DealScan database, excluding nonU.S. borrowers and firms in SIC codes 6000-6999 (financial institutions etc) and 9000-9999 (government agencies etc). LPC lists 15,273 borrowers between 1988 and June 2002, taking out 49,459 loan facilities totaling \$8 trillion. We are able to hand-match 6,701 LPC borrowers by name (LPC's principal firm identifier) to our sample of SDC issuers. These account for 30,068 of the 49,459 loan facilities, or $60.79 \%$ by number and $79.92 \%$ by loan amount. ${ }^{9}$ In the case of syndicated loans, each bank with in a leading role (i.e. 'arranger') is credited with the corresponding fraction of the loan. ${ }^{10}$

As Table 3 shows, the average winning bank had relatively weak lending relationships with equity issuers, in sharp contrast to the importance of prior equity underwriting relationships. For instance, winning banks providing coverage arranged only $2.6 \%$ of the average equity issuer's loans in the prior 5 years. Among debt issuers, lending relationships are somewhat more concentrated, peaking at $7.2 \%$ among winning banks not providing coverage. Not coincidentally, Table 3 also confirms the well-known fact that commercial banks enjoyed considerable success in the debt markets. Of course, prior lending relationships need not proxy solely for 'tied' loans. Yasuda (2003) shows that bond issuers that hire their lenders as underwriter obtain keener prices, suggesting that lenders having greater certification capacity.

Commercial banks' larger balance sheets almost certainly provided greater capacity for sweetening bids for underwriting mandates by including a loan. Thus, we also compute each bank's share of the corporate loan market in the calendar year before the deal in question, based on loans arranged as a proxy

\footnotetext{
${ }^{9}$ Of the remaining 8,572 borrowers not matched to SDC, 1,678 can be matched to the CRSP master tape, so we can definitively rule out that they are in SDC (since we can merge SDC and CRSP without a problem). This leaves unmatched 6,894 borrowers taking out 14,344 loans for $\$ 1.3$ trillion $(16.25 \%$ of the total). It is possible that some of these are in fact in SDC, but given the above numbers, we are confident that we have captured the vast majority of lending activity.

${ }^{10}$ Yasuda (2003) shows that lending relationships are strongest at the 'arranger' level, though widening the scope to include 'lead managers' leaves her results unaffected.
} 
for their capacity to sweeten their bids or tie lending to capital market transactions. Descriptive statistics are reported in Table 3. Whether or not they provided coverage, large lenders more often failed in the competition for equity deals while succeeding in competition for debt mandates.

\subsection{Bank Reputation, Equity Stakes in Issuers, and Key-Banker Movements}

The sample period witnessed a high frequency of bank consolidation and associated disruptions, an increasing frequency of banks holding equity stakes in potential issuers, and a generally high level of mobility among bankers in whom relationships often are embodied. Thus we complement the bank-issuer relationship measure described in the previous section with measures of bank market share, equity stakes in issuing firms, and key-banker movements designed to reflect information not captured by an issuer's history of mandates granted to a particular bank.

We use prior-year market share to proxy for a bank's reputation for success in securities underwriting (Megginson and Weiss (1991)). Among the summary statistics provided for this variable (separately for debt and equity) in Table 3, two patterns stand out. First, banks that win underwriting mandates are more reputable as evidenced by their higher market shares. Second, this is true whether or not the bank provides research coverage. The differences are particularly large for debt transactions.

The market share reputation proxy is complemented by Institutional Investor's assessment of a bank's overall reputation for research quality as of the calendar year preceding the transaction in question. Institutional Investor ranks banks on the number of analysts or teams that are rated "all-star" in the annual survey. Winning banks have consistently more 'all-star' analysts, whether or not the issuer's stock is covered. On average, banks that win underwriting mandates also provide somewhat broader research coverage for the issuer's industry, measured as the fraction of firms in the issuer's Fama-French (1997) industry grouping the bank currently covers.

Ljungqvist and Wilhelm (2003) document a sharp rise from $18.2 \%$ in 1996 to $44 \%$ in 2000 in the frequency of banks having stakes in firms whose IPOs they underwrite. We measure whether this means of cementing a banking relationship was part of a broader trend by merging our sample of issuers 
with the Spectrum $13 f$ data on equity stakes held by financial institutions. For each deal, we check whether any sample bank active at that time reported an equity holding in the issuer or its corporate parent as of the quarter-end prior to the deal. ${ }^{11}$ Table 3 indicates a generally high frequency of equity stakes among banks winning underwriting mandates. The exception involves equity transactions prior to which the bank did not provide research coverage. This segment of the sample is dominated by commercial banks that for most of the period were prevented by regulation from holding equity stakes in their clients.

The high degree of mobility among investment bankers creates potential for relationship shocks not captured by transaction-based measures of prior relationships. In general, both theory and casual evidence suggest that client relationships are embodied, perhaps in large part, in individual bankers. Thus their movement should influence the probability of receiving a mandate faced by both the firm they join and the one from which they defected. ${ }^{12}$

We control for this effect by tracking the movement of key bankers or teams of bankers during each quarter in the estimation period. We searched electronically through the major business periodicals covered by Lexis/Nexis and Proquest to identify individuals or teams who most likely played key roles in developing and maintaining client relationships. The bulk of the sample came from Investment Dealers' Digest, which over the period of 1990-2002Q2 provides weekly reports of the movements of high profile bankers. In general, we focused on movements by bankers at the rank of managing director (or its equivalent) and above, except in cases where a less senior banker is part of a team or small group of bankers switching firms. We classified key bankers as equity or debt specialists. The latter classification is more precise in the sense that debt specialists were more typically identified clearly as such. In general, M\&A professionals were classified as equity specialists. We excluded cases involving prominent traders, foreign exchange, mortgage-backed securities and derivatives professionals as well as senior bankers

\footnotetext{
${ }^{11}$ The Spectrum 13f data of institutional holdings are filed with the SEC on a quarterly basis. We match the names of filers to our sample banks using where necessary Nelson's Directory of Investment Managers. We thank Edie Hotchkiss for help in performing the match.

${ }^{12}$ See Anand and Galetovic (2000) for a discussion of competition among investment banks when client relationships are embodied in key employees and therefore non-excludable. Eccles and Crane (1988) provide numerous examples from their survey of bankers and their clients supporting this claim.
} 
primarily involved in management functions. We also excluded professionals whose primary responsibilities fell outside North America. This search yielded a sample of 169 records. ${ }^{13}$

In many instances, reported defections probably understate the potential damage to client relationships. Most bank acquisitions were followed by a substantial degree of movement although not necessarily at the most senior level where completion of the deal may have depended on bankers signing commitments that would prevent them from joining competitors for a fixed period. To avoid not detecting what may be a substantial reordering of banking relationships, we code whether the bank was involved in a merger during the quarter in which the sample deal took place.

\subsection{Analyst Behavior}

We measure analyst behavior using data from the I/B/E/S “recommendations" database. I/B/E/S tracks analyst recommendations from late October 1993, covering roughly 10,000 firms, 8,000 analysts, and 500 banks. Sample firms are matched to I/B/E/S using the corporate parent's CUSIP if possible and the issuing firm's CUSIP otherwise. Using this algorithm, 3,472 of the 6,821 sample companies and 2,562 of the 5,472 unique corporate families match firms covered in I/B/E/S. Some of these matches do not correspond with analyst coverage provided by a sample bank. Among the 16,625 sample deals, 10,717 are by issuers covered by at least one sample bank prior to the deal. Issuers that do not appear in I/B/E/S around their deal dates are treated as not receiving coverage from a sample bank.

Table 4 provides descriptive statistics for the deals and issuing firms, according to whether or not they received coverage. As one might expect, for both equity and debt deals, firms receiving research coverage from sample banks were significantly larger (as measured by deal size), more frequent and substantial issuers of securities (as evidenced by their deal histories), more mature (as measured by the time from their IPO), and more frequently listed.

\footnotetext{
${ }^{13}$ Some records involve a defection from one sample bank to another, so the number of independent records is much smaller. As one might expect, banker defections cluster for two reasons: an acquisition or a high level of market activity in the banker's area of specialization. When several key bankers defect in close proximity to one another, existing relationships are more likely to suffer. When bankers actually move as teams to a competitor, it is more likely that an existing relationship survived and moved with them. When it was stated explicitly that bankers moved as a team, we coded their movement separately as a team movement. Our estimation results are robust to focusing only on team movements.
} 
$\mathrm{I} / \mathrm{B} / \mathrm{E} / \mathrm{S}$ codes recommendations from 1 (strong buy) to 5 (sell). ${ }^{14} \mathrm{We}$ reverse the ordering so that larger numbers indicate more positive recommendations. New, reiterated, or changed recommendations arrive, and are recorded by I/B/E/S, irregularly rather than on a monthly or quarterly basis. Thus, the most recent recommendation for a given firm by a given bank and its analyst will not necessarily correspond in time with the most recent recommendation from a competing bank. We resolve the time-matching problem by requiring that the most recent estimate for a given firm issuing debt or equity be no earlier than 730 days (two years) prior to the transaction date. This window balances concerns that recommendations associated with sample banks competing for a given underwriting mandate are relatively close in time with concerns that a narrow window potentially eliminates relevant forecasts. On average, recommendations associated with a particular securities offering were recorded 270 days before the transaction date, with a median of 220 days and a standard deviation of 200 days. ${ }^{15}$

We construct two proxies for analyst behavior. The first measures bank $j$ 's recommendation level relative to its peer banks by subtracting from its most recent recommendation the median recommendation of all sample banks covering firm $i$ in the 730-day window before $i$ 's transaction. By construction, relative recommendations lie between -4 and +4 . Positive values correspond to relatively optimistic recommendations.

Recent allegations (such as those arising from the Congressional investigation of Salomon Smith Barney's pursuit of AT\&T Wireless's IPO in 2000) center not on the level of recommendations but on analysts aggressively upgrading their recommendations prior to the award of an underwriting mandate. We examine these allegations by constructing a second measure focusing on relative recommendation upgrades. For each bank we calculate the change between the two most recent recommendations prior to a deal. If the analyst does not issue a new recommendation in the 275 days (nine months) before the deal, we assume the prior recommendation still stands, implying a zero upgrade. If the analyst's first

\footnotetext{
${ }^{14}$ Strong buys account for $25 \%$ of recommendations, $36 \%$ are buy recommendations, $37 \%$ are hold recommendations, $1.4 \%$ are under-perform recommendations and $0.6 \%$ are sell recommendations.

${ }^{15}$ All results are robust to Lin and McNichols' (1998) selection criterion that the most recent recommendation be no earlier than one year prior to the offer date.
} 
recommendation (i.e. initiation of coverage) occurs in the 275 days prior to the deal, we assume that the bank previously was neutral toward the issuer (recommendation level 3) and measure the relative upgrade as the difference between the recommendation at coverage initiation and the assumed neutral prior recommendation. The relative upgrade is then defined as a bank's recommendation change for firm $i$ less the median change for all sample banks. Like the relative recommendation measure, relative upgrades lie between -4 and +4 , with positive values representing relatively aggressive upgrades. ${ }^{16}$

The relative upgrade measure has two potential shortcomings. Not surprisingly, it is zero for the majority of firms and so exhibits less variance than do relative recommendations. Moreover, a bank can provide a relative upgrade but still be relatively less optimistic than another bank identified as providing no upgrade. For example, Goldman's analyst might have rated IBM as a "5" (strong buy) and not altered her opinion before the deal date, while Bear Stearns' analyst might have upgraded IBM from " 2 " to " 3 ". Bear Stearns would be considered to have upgraded the stock more aggressively than Goldman, even though Goldman's analyst had a higher recommendation level which could not be increased further. To account for this, our model for relative upgrades will include a dummy equaling one if the last-but-one recommendation was already a "strong buy", so that a further upgrade would have been impossible. ${ }^{17}$ In summary, the relative upgrade measure emphasizes whether the analyst changes her opinion while the relative recommendation measure focuses on the (relative) strength or level of the analyst's opinion.

Table 5 shows that by either measure, analysts at winning banks were more aggressive in their recommendations, especially prior to debt deals. These results extend the findings of Michaely and Womack (1999) and Bradley, Jordan, and Ritter (2003) who show that after underwriting an IPO, underwriter-affiliated analysts are relatively more optimistic. However, the differences between the unconditional means are economically small, and there is no difference between the medians.

Table 5 also summarizes three controls for reputation-related career concerns. The first is based on

\footnotetext{
${ }^{16}$ Our results are robust to instead subtracting the mean recommendation or upgrade of sample banks, defining the peer group to include all banks (rather than sample banks), or defining relative recommendations and upgrades as dummy variables equal to one if the sample bank is relatively more aggressive than its peers.

${ }^{17}$ This does not drive our results.
} 
buy-side evaluations reflected in the annual Institutional Investor analyst rankings. We match these rankings to I/B/E/S records by broker and analyst name. For a deal at time $t$, we define a dummy to equal 1 if bank $j$ 's analyst covering the stock was an 'all-star' (i.e. ranked among the top four analysts in her industry) in the most recent poll preceding the deal. Among equity (debt) deals, $36.2 \%(44.0 \%)$ of winning banks have an all-star analyst covering the issuer versus only $27.7 \%$ (36.9\%) for losing banks.

Second, assuming analyst reputation derives, at least in part, from forecasting ability, we measure forecast accuracy as in Hong and Kubik (2003). We compute the absolute forecast error of each analyst $a$ covering firm $i$ in year $t$ as the difference between the analyst's most recent forecast of year-end earnings per share (issued between January 1 and July 1 of that year) and subsequent realized earnings, scaled by price (measured as of the prior December). Absolute forecast errors are sorted by size, and the "best" (most accurate) analyst is assigned a rank of 1 , the second best a rank of 2 , and so forth. ${ }^{18}$ To address possible biases in rank due to variation across firms in the number $N_{i, t}$ of analysts providing coverage, the analyst's rank is then scaled as follows:

$$
\text { Score }_{a, i, t}=\left(1-\frac{\text { Rank }-1}{N_{i, t}-1}\right) \cdot 100
$$

Thus the most accurate analyst scores 100 and the least accurate zero. We reduce noise by defining an analyst's relative forecast accuracy as her average score in years $t$ - 2 to $t$. Table 5 reveals relative forecast accuracy to average around 50, with a distribution similar to that reported by Hong and Kubik.

Finally, we measure the analyst's seniority as the number of years in which she appears in the I/B/E/S database. Hong et al. (2000) find that analysts are less bold early in their careers and more likely to exit the profession following inaccurate or relatively bold forecasts. For both equity and debt deals, analysts at winning banks in our sample are more senior.

\footnotetext{
${ }^{18}$ In the event of a tie such as the fourth and fifth rated analysts having the same forecast error, each receives the fourth ranking and the next analyst is ranked sixth.
} 


\section{Estimation Results}

Estimation results are reported in three steps. Section 4.1 provides a summary of the results from estimating the switching criterion given in (6). Whether bank $j$ covers an issuing firm $i$ 's stock at time $t$ determines whether we observe system (4) or system (5). In the presence of coverage, we use a two-step procedure to estimate system (4). The first step estimates the determinants of analyst behavior adjusted for truncation due to non-coverage. These are reported in Section 4.2 for each measure of analyst behavior described in the preceding section. In the second step, we model the probability of winning the underwriting mandate as a function of the predicted values for the measures of analyst behavior obtained in step 1, again adjusted for truncation. In the absence of coverage, analyst behavior is unobserved and we estimate system (5) as a single-equation model with truncation. The results for these underwriting mandate probability models are reported in Section 4.3.

\subsection{Stage 1: The Bank Coverage Model}

We follow Ljungqvist, Marston, and Wilhelm (2003) in modelling bank coverage in equation (6) but in the interest of brevity do not report detailed results from this stage of estimation. ${ }^{19}$ The model is estimated separately for equity and debt deals and interacts each explanatory variable with a dummy variable equal to 1 for commercial banks. Like Ljungqvist, Marston, and Wilhelm, we find that a firm's stock is more likely to be covered prior to a capital market transaction,

- the stronger the relationships between bank and issuer,

- the larger the bank (in terms of market share),

- when the bank already has an analyst in place covering the issuer's industry,

- the larger the issuer's fee-generation capacity (measured by the log of the size of the current deal and the log of the issuer's equity or debt proceeds raised during the previous five years),

- the more mature the firm (measured in log years since its initial public offering of equity),

\footnotetext{
${ }^{19}$ Ljungqvist, Marston, and Wilhelm (2003) study the linkage between investment-banking relationships and research coverage over the period 1988 to 2002 and provide a detailed analysis of the bank coverage model used here. In general, the explanatory power is quite high in both the equity and debt samples, with pseudo $R^{2}$ in excess of $35 \%$.
} 
- among U.S. firms,

- and for exchange-listed firms.

In general, the magnitude of these effects is smaller for commercial banks, which, all else equal, were less likely to provide coverage. In sum, the research coverage models reveal the coverage decision to be heavily influenced by variables associated with the strength of a bank's relationship with the issuing firm and the issuing firm's capacity for sustaining such relationships via fee-generating transactions.

Commercial banks were latecomers to the provision of research by virtue of Glass-Steagall restrictions on their participation in securities markets. Where they did provide coverage, the evidence suggests it was more closely linked with a past underwriting relationship than for the investment banks that traditionally provided broader coverage as a complement to their brokerage activities.

\subsection{The Analyst Behavior Models}

The primary purpose of the analyst behavior models is to generate instruments for use in the lead bank probability model, so we confine our discussion to the most noteworthy findings. Table 6 presents estimation results for the analyst behavior model in structural form, for each of the two proxies for analyst behavior. (The reduced forms used to generate the instruments include also the exogenous variables from the lead-bank equation and are not shown.) The models are estimated separately for debt and equity deals. The relative upgrade specifications include a dummy variable equaling one if the last-but-one recommendation was already a strong buy, ruling out a further upgrade (the coefficients, which are negative as expected and strongly significant, are not reported). ${ }^{20}$

Consistent with prior evidence regarding IPO underwriters, analysts are relatively more aggressive when their bank has a strong relationship with the issuer. Relative recommendations and relative upgrades are more aggressive, the greater the bank's shares of the issuer's past debt and equity proceeds and among banks with equity stakes in the issuing firm. The effects are present in both equity and debt transactions

\footnotetext{
${ }^{20}$ As a robustness check, we have repeated our analysis on a sub-sample that drops all cases where the last-but-one recommendation was a strong buy, so that the relative upgrade specification no longer requires inclusion of the dummy. All our results are qualitatively unaffected.
} 
and generally statistically significant. ${ }^{21}$

A strong reputation in the equity market provides a countervailing force: banks with large equity market shares are associated with significantly less aggressive analyst behavior ahead of both equity and debt deals. In contrast, large debt-market and loan-market shares are associated with more aggressive recommendations, especially for the debt sample. In reconciling these apparently conflicting effects, it is useful to recall that equity transactions suffer more under the burden of informational frictions and so the intermediary's reputation has a more prominent role in certifying issuer quality. One should therefore expect that banks with strong reputations in the equity capital market would be less inclined to liquidate reputation capital via overly aggressive recommendations.

On the other hand, during the estimation period, commercial banks gained substantial market share in the debt markets (in part entering via the corporate loan market) where an intermediary's reputation poses a weaker barrier to entry. Their gains came largely at the expense of lower-ranked investment banks. Other things equal, less reputable banks (both commercial and investment) faced weaker countervailing forces to their incentive to compete for debt mandates via more aggressive analyst behavior.

The relative upgrade proxy reflects recent changes in analyst recommendations. As such, it more nearly captures the idea that banks pressured analysts to position their recommendations to help the bank compete for a specific deal. If banks less closely aligned with the issuer compete for deal flow with more aggressive upgrades, we should observe an attenuation of the positive relation between analyst behavior and the bank-issuer relationship proxies observed in the relative recommendation model. This appears to be the case. For equity deals, the relationship variables cease to be significant, while for debt deals, the coefficients associated with the bank's debt underwriting and lending relationships are significantly

\footnotetext{
${ }^{21}$ Banks generally are thought to act as intermediaries in securities offerings balancing the competing interests of issuers and institutional investors. One might expect banks to favor one side or the other locally as they compete for new business opportunities but not globally in equilibrium. Thus the apparent tendency for banks to issue more aggressive recommendations for firms with which they already have strong relationships begs for further consideration. If institutional investors do not take such upgrades particularly seriously or any negative consequences can be offset by other means, then perhaps this is a relatively low-cost form of non-price competition of the sort envisioned by Anand and Galetovic (2002). Alternatively, it might reflect banks colluding with issuers against investors during our estimation period. Distinguishing between these and other potential explanations requires additional modeling to incorporate the relationship between banks and institutional investors.
} 
smaller than in the relative recommendations specification.

Relative upgrades are less aggressive among all-star analysts suggesting that career concerns moderate analysts' incentives to bend to investment bankers' demands. The moderating effect of all-star status is reversed during the 1999-2000 period usually associated with the 'dot-com bubble' during which the potential rewards for sacrificing one's individual reputation might have been greater. As a proxy for the size of the potential rewards, we calculate the percentage difference in market-wide proceeds raised during the current quarter and a five-year quarterly moving average, and interact it with the bank's overall market share..$^{22}$ As market-wide issuance activity increased, analysts behaved more aggressively when their bank was more likely to capture a large share, and this effect is statistically significant ahead of debt deals. Similarly, large deals attract more aggressive upgrades, consistent with analysts trading off reputational concerns and the bank's ability to generate fee income. Among debt transactions, recommendations are more aggressive for the less active issuers. We conjecture that this reflects more aggressive competition for less active issuers under the assumption that more active issuers had stronger banking relationships in place.

Finally, more accurate forecasting ability is associated with more aggressive behavior in each debt specification, with much weaker evidence in the equity specifications. This is consistent with the debt markets being the point of entry for commercial banks and non bulge-bracket investment banks responding to competitive pressure in this market segment by liquidating reputation capital.

Heckman's $\lambda$ is an estimate of the effect of the probability of non-coverage on analyst behavior. The positive coefficients reported in Table 6 suggest that analysts behave more aggressively ahead of deals by issuers whose stock they are unlikely to cover (according to the coverage model). Conversely, companies that are more likely to be covered anyway receive less aggressive recommendations and upgrades.

\section{Instrument Validity}

To ensure that our models are identified, the first-step (analyst behavior) equations include a set of six

\footnotetext{
${ }^{22}$ Our results are robust to using shorter windows and to defining the variable separately for equity and debt deals.
} 
instruments that are excluded from the second-step (lead bank) probits, namely relative forecast accuracy, analyst seniority, the change in issue activity and its interaction with the bank's market share, deal size, and the issuer's cumulative proceeds over the prior five years. Economically, these are reasonable instruments: the analyst's tradeoff between the costs and benefits of risking her reputation reasonably affects the observed degree of relative aggressiveness without directly bearing on an issuing company's choice of underwriter. Moreover, a given issuer's deal size and five-year deal history do not vary across banks and so cannot determine the issuer's underwriter choice.

Econometrically, we verify that these are valid instruments in the sense that one or more of them correlate with analyst behavior but not with the second-step dependent variable. This is true for three of the four analyst behavior models, with $F$-test statistics in excess of 10 , the critical value for 'strong' instruments advocated by Staiger and Stock (1997). The exception is the relative recommendation specification in the equity sample. There, five of the potential instruments are uncorrelated with the second-step dependent variable as required, but their partial correlation with analyst behavior in the reduced-form model is low $(F=3.28)$, making them 'weak' instruments in the sense of Staiger and Stock. This has two consequences: the two-step estimator in the equity sample will likely not improve on a onestep estimator that treats relative recommendations as exogenous; and the second-step standard errors for this specification will be imprecise because the Murphy-Topel correction is partly based on the first-step covariance matrix.

\subsection{The Determinants of the Probability of Winning an Underwriting Mandate}

Having estimated the bank coverage and analyst behavior equations, we now condition the probability of a bank winning an underwriting mandate on its potentially strategic decision regarding whether to cover the issuing firm and if so, on the relative optimism of its analyst's recommendation.

\section{Equity Transactions}

Table 7 summarizes the results from estimating the underwriting mandate model for equity transactions. Conditional on a bank providing research coverage, there are two specifications in the 
table, one for each measure of analyst behavior. These correspond to system (4) in Section 2. In addition, we estimate the likelihood of winning a deal in the absence of coverage (system (5)).

The first striking result is that among equity deals, relative upgrades reduce a bank's chances of win a deal mandate $(p<0.001)$. This finding runs counter to the spirit of previous research and the arguments embodied in recent allegations. ${ }^{23}$ Interpreting aggressive upgrades as liquidation of reputation capital, this strategy appears particularly ineffective in the case of equity offerings where reputation is viewed as more central to successful placement. Banks pressed to compete on this dimension fought a losing battle.

The relative recommendation measure, on the other hand, carries the expected positive coefficient but the effect is not statistically significant. Recall however that our instruments for this specification are weak, so the two-step estimator may not improve on a simple one-step estimator treating relative recommendations as exogenous. In other words, in the absence of better instruments, it is unclear what effect aggressive recommendations have on a bank's likelihood of winning an equity mandate.

If aggressive analyst behavior does not attract equity mandates, what does? The strength of the bankissuer relationship (measured as the bank's shares of the issuer's prior equity or debt issuance and borrowing or when the bank owns an equity stake in the issuer) strongly increases the likelihood of the bank winning the issuer's current underwriting mandate. Judging from the magnitude of the coefficients, ${ }^{24}$ relationships derived from prior equity deals influence the choice of equity underwriter more than those based on prior debt deals. The fact that lending relationships help win equity mandates is consistent with allegations that commercial banks attempted to tie lending capacity to securities underwriting. ${ }^{25}$ Relationships are significantly more important when the bank did not provide coverage for the issuer during the event window preceding its equity offering. This is consistent with issuing firms valuing

\footnotetext{
${ }^{23}$ It also illustrates the importance of accounting for sample truncation and the endogeneity of analyst behavior arising from their career concerns. Had we treated analyst behavior as exogenous, the sign on the coefficient for relative upgrades would have flipped to become positive $(p<0.001)$. However, a formal Smith-Blundell (1986) test rejects the null hypothesis that analyst behavior is exogenous with respect to the lead bank choice in our data $(p<0.0001)$.

${ }^{24}$ This being a probit with sample selection correction, the error variance has been normalized to one, so we cannot measure the economic magnitudes corresponding to the estimated coefficients. We can, however, make statements about the relative size of the coefficients.

${ }^{25}$ Drucker and Puri (2002) find that discounting loans increases the likelihood of winning SEO underwriting mandates.
} 
research coverage but making tradeoffs at the margin between coverage and the strength of their relationships with banks competing for their mandate.

Banks involved in mergers during the quarter preceding an issuer's transaction were more likely to win mandates, suggesting that at least some of the target bank's relationships transferred to the acquirer. The effect is strongest in the absence of coverage where issuers might expect the merger to result in broader research coverage (including the issuer). Movements of key bankers, on the other hand, have little effect on the likelihood of winning an equity mandate, except in the absence of coverage where hiring bankers increased and losing bankers decreased the chances of winning an equity mandate.

The coefficients associated with analyst reputation provide further evidence that issuers value research capability in equity offerings. ${ }^{26}$ Having an all-star analyst providing research coverage for the issuing firm significantly increases a bank's likelihood of winning the mandate. In the absence of direct coverage of the issuer prior to an equity deal, however, banks that have large teams of all-star analysts are less likely to win the mandate. This suggests that equity issuers punish a failure to provide coverage.

The coefficients for the bank's market share in the prior year suggest that a strong reputation in the equity market at large increases the likelihood of winning a mandate regardless of whether the bank provides coverage for the issuing firm. By contrast, a strong position in the debt or loan markets has no bearing on competition when the bank provides coverage. Once again, we interpret this as evidence of a degree of bank specialization in either debt or equity. In the absence of coverage, large lenders - that is, commercial banks - were less likely to win equity mandates, significantly so when they did not provide research coverage. Thus while having a lending relationship helps, just being a large lender does not.

\section{Debt Transactions}

Table 8 reveals that more aggressive recommendations and upgrades significantly decreased the likelihood of winning debt-underwriting mandates ( $p<0.001$ and $p=0.021$, respectively). The main

\footnotetext{
${ }^{26}$ The perceived value of coverage could have many sources. Chan et al. (2003) find that analysts in the U.S. help firms avoid negative earnings surprises.
} 
difference from the equity results rests with the effects of our proxy for a bank's lending capacity. Here we find that a larger share of the corporate loan market increased a bank's probability of winning debt-underwriting mandates $(p<0.001)$. This result is consistent with the argument that competitive pressure from the 'pay-to-play' movement initiated by commercial banks had its greatest impact in the debt markets. Both the analyst behavior coefficients and the large gains in debt-market share among commercial banks even in the early part of the 1990s suggest that liquidation of reputation capital was not an effective competitive response, at least not across the entire estimation period. In the next section, we examine whether the effectiveness of this competitive strategy changed over time.

As with equity deals, prior relationships strongly influence issuers' choices of debt underwriters. This is true for both prior debt and equity deals, though consistent with specialization and mirroring the results for the equity sample, relationships derived from having underwritten an issuer's prior offerings of like securities are most effective. Lending relationships too help win debt mandates.

In contrast to the equity results, owning an equity stake in the issuing firm had little effect on the likelihood of winning debt mandates when the bank provided coverage, and a negative effect when it did not. Commercial banks and non-bulge-bracket investment banks accounted for the bulk of the cases where no research coverage was provided. Commercial banks were prohibited from holding equity stakes during the first half of the estimation period. Moreover, commercial banks gained substantial debt-market share largely at the expense of non-bulge-bracket investment banks (at least through 1998). Thus we favor the interpretation that in the absence of coverage, lending relationships dominated any positive relationship effects associated with equity ownership. As a consequence, we observe a negative relation between bank equity stakes (mostly held by investment banks) and the likelihood of winning a debt mandate in the absence of coverage. Regardless of this interpretation, commercial banks appear to have gained leverage in the debt markets via their lending capacity.

Unlike the equity case, mergers had only a marginal effect on winning debt mandates, though movements of key bankers, which often coincided with mergers, had the expected effect: a bank's 
chances of winning a mandate were lower when it recently had lost key members of its debt team and higher when it had poached debt professionals from other banks. This finding suggests that relationships are embodied in key people.

When they provided coverage, banks with larger teams of all-star (debt) analysts were significantly more likely to win debt mandates, but mirroring our findings for equity deals, the sign changes when their analysts did not cover the issuer's stock. This again suggests that issuers punish non-coverage. On the other hand, having an all-star analyst covering the issuer's stock had either no effect or a negative effect on whether the analyst's bank was awarded the debt-underwriting mandate.

The coefficients associated with a bank's debt and equity market share during the calendar year preceding a transaction provide further evidence of bank specialization in either debt or equity. Banks with larger debt market shares were more likely to win subsequent debt mandates, similar to the direct effect of equity market share on the likelihood of winning subsequent equity mandates. By contrast, banks with larger equity market shares were less likely to win debt-underwriting mandates, other things equal.

\section{Differences Across Time}

Table 9 reports coefficients for the instrument for analyst behavior during the 1993-1997 and 1998June 2002 sub-periods. The rationale for partitioning the estimation period is that the end of the first subperiod corresponds roughly with the de facto repeal of the Glass-Steagall Act revealed by the approval of Citicorp's acquisition of Salomon Smith Barney in 1998 and the beginning of the 'dot-com bubble' with which allegations of analyst misbehavior primarily are associated. We estimate the full model discussed previously but to conserve space, we suppress all but the analyst-behavior coefficients. The remainder of the model is quite stable across the sub-periods and so we simply highlight instances in which partitioning the data leads to qualitative changes in our interpretation of the results.

The results across the two sub-periods for the equity sample are remarkably stable. There is no evidence that analyst behavior positively influenced the likelihood of winning equity-underwriting mandates, even after 1997. On the contrary: banks whose analysts upgraded issuers' stocks more 
aggressively were less likely to win mandates in either period, with a larger (more significant) effect post-1997. To gain further insight, we interact the analyst behavior instruments with a dummy equaling one for deals completed during the bubble years (1999 and 2000), but find no evidence that analyst behavior had a differential effect on issuers' choices during that period (not shown in the table).

The main changes over time for the equity sample concern the increasing importance of a highly-rated analyst and a strong overall research reputation and the (relatively) decreasing importance of prior lending relationships (which go from being three times more effective than debt relationships and nearly as effective as equity relationships to being the least important source of a bank's relationship benefits).

The picture is somewhat different for debt deals. The relative recommendation specification reveals a significant positive effect on the likelihood of winning a debt-underwriting mandate during the post-1997 period $(p<0.001)$. Similarly, the relative upgrade specification no longer suggests that aggressive upgrades undermined a bank's efforts to attract debt mandates post-1997. In sum, if liquidation of reputation capital was an effective competitive response, it appears to have been so only in the debt markets and only during the post-1997 period. The general pattern is consistent with the presence of less severe information frictions in debt offerings. The apparent net benefit from liquidating reputation capital appeared as issuers aggressively pressured investment banks to meet commercial bank offers to couple lending facilities with capital market transactions. Absent comparable lending capacity in the short run, one might conclude that some investment banks successfully liquidated reputation capital as a substitute.

There are two additional significant differences across the two time periods. In contrast to the equity model, the presence of an all-star analyst - typically employed at an investment bank - reduced the likelihood of winning debt mandates during the post-1997 period. Second, holding an equity stake in the issuer helped the bank win the mandate only in the pre-1998 period. A natural interpretation of this finding is that by 1998, the easing of restrictions on holding equity stakes helped level the playing field between investment banks and commercial banks. 


\section{Conclusion}

We examine 16,625 U.S. debt and equity offerings sold between December 1993 and June 2002 for evidence that research analyst behavior influenced the issuer's choice of bank to underwrite its offering. This is precisely the motivation suggested by recent allegations that analysts misrepresented their beliefs about potential issuers under pressure from investment bankers competing for underwriting mandates. Our findings provide at best modest support for this argument but, more importantly, they draw attention to the complexity of the situation and some unique features of the sample period. ${ }^{27}$

In the equity markets, we find no evidence that banks gained competitive advantage via aggressive recommendation behavior among their analysts. In fact, aggressive recommendation upgrades undermined a bank's chances of winning equity mandates. In general, the state of bank-issuer relationships and the reputation of both the bank and the analyst had far more influence over the outcome of competition for equity mandates.

Recent allegations related to aggressive analyst behavior have arisen primarily in the context of the equity markets. Seen in this light, our findings may strike some readers as surprising if not implausible. However, there is a straightforward economic argument consistent with the negative relation between aggressive recommendations and the likelihood of winning equity mandates. Equity transactions are subject to significant information frictions that are best resolved by a credible intermediary. Overly aggressive recommendations undermine credibility and thus compromise a bank's capacity for resolving information frictions.

The information frictions that make credibility so important for equity underwriting are less severe in

\footnotetext{
${ }^{27}$ Relative to existing research, our research design de-emphasizes the initial public offering by examining all capital market transactions by an issuer during the sample period. From a theoretical perspective we contend that an issuer's transactions with a bank should not be treated as independent events. Our evidence is consistent with this argument. From a practical perspective, relatively few firms attract analyst research coverage prior to their IPO and thus most IPOs are classified as nocoverage cases in our sample. The exception is carve-outs by parents whose stocks are already covered. In this sub-sample, we still find that aggressive analyst behavior failed to help banks win business. We note, however, that anecdotal evidence suggests that banks and their analysts competed for IPO underwriting mandates by making (non-binding) commitments to provide favorable research coverage. Although such behavior is relevant to the question at hand, it is econometrically unobservable and thus we cannot determine how it influenced the issuer's choice of underwriter. The finding by Cliff and Denis (2002) that firms are more likely to switch underwriters when they receive less coverage than expected is consistent with punishment for violation of such implied contracts.
} 
debt offerings. It is therefore noteworthy that aggressive recommendations were less damaging to efforts to win debt-underwriting mandates and may even have proved beneficial during the post-1997 period as commercial banks became more aggressive in their attempts to tie lending facilities to capital market underwriting mandates.

The conflict of interest between investment banking and research is longstanding and yet only recently has it come under heavy criticism. In light of calls for heavier regulation or even separation of research from investment banking, it is important to note that our econometric model embodies both the market forces that moderate the conflict and more recent, inflammatory factors. Both banks and individual analysts have incentive to build and preserve reputations for accuracy and honesty in their research. We find evidence of this moderating force at work in the data. Building and preserving reputation capital served banks well in competition for equity mandates, in particular.

Success in securities underwriting has long depended heavily on reputation and the strength of the bank's relationship with a potential issuer. Unless there is reason to believe that the fundamentals of securities underwriting have changed, we contend that preservation rather than liquidation of reputation capital is more characteristic of equilibrium behavior. It does not follow that our findings absolve analysts and their banks from any alleged misbehavior. In fact, we find some evidence that competition for the massive fee pool available in the late 1990s overwhelmed the moderating effect of reputational concerns. But even with an unusually large fee pool at stake, banks should not grossly misrepresent their beliefs about issuers unless they expect misrepresentations to favorably influence investor behavior. Perhaps not coincidentally, the late 1990s were unusual for witnessing a temporarily high level of participation among, presumably less sophisticated, retail investors. 


\section{References}

Abarbanell, Jeffrey S., 1991, Do analysts' earnings forecasts incorporate information in prior stock price changes? Journal of Accounting and Economics 14, 147-165.

Anand, Bharat, and Alexander Galetovic, 2000, Information, non-excludability and financial market structure, Journal of Business 73, 357-402.

Anand, Bharat, and Alexander Galetovic, 2002, Does competition kill relationships? Inside investment banking, unpublished working paper, Harvard Business School.

Baker, Wayne, 1990, Market networks and corporate behavior, American Journal of Sociology 96, 589625.

Boot, Arnoud, and Anjan V. Thakor, 2000, Can relationship banking survive competition? Journal of Finance 55, 679-713.

Bradley, Daniel J., Bradford D. Jordan, and Jay R. Ritter, 2003, The quiet period goes out with a bang, Journal of Finance 58, 1-36.

Brown, Phillip, George Foster, and Eric Noreen, 1985, Security Analyst Multi-Year Earnings Forecasts and the Capital Market (American Accounting Association, Sarasota, Fl.).

Chan, Louis K.C., Jason Karceski, and Josef Lakonishok, 2003, Analysts' conflict of interest and biases in earnings forecasts, NBER Working Paper No. 9544.

Chemmanur, Thomas, and Paolo Fulghieri, 1994, Investment bank reputation, information production, and financial intermediation, Journal of Finance 49, 57-80.

Chopra, Vijay K., 1998, Why so much error in analysts' earnings forecasts? Financial Analysts Journal $54,30-37$.

Clarke, Jonathan, Craig Dunbar, and Kathleen Kahle, 2002, All-star analyst turnover, investment bank market share, and the performance of initial public offerings, unpublished working paper, University of Western Ontario.

Cliff, Michael T., and David J. Denis, 2002, Do IPO firms purchase analyst coverage with underpricing? Unpublished working paper, Purdue University.

Diamond, Douglas, 1991, Monitoring and reputation: The choice between bank loans and privately placed debt, Journal of Political Economy 99, 689-721.

Dreman, David, and Michael Berry, 1995, Analyst forecasting errors and their implications for security analysis, Financial Analysts Journal 51, 30-42.

Drucker, Steven, and Manju Puri, 2003, Tying knots: Lending to win equity underwriting business, unpublished working paper, Stanford University.

Eccles, Robert G., and Dwight B. Crane, 1988, Doing Deals: Investment Banks at Work (Boston, Harvard Business School Press). 
Fama, Eugene, and Kenneth French, 1997, Industry costs of equity, Journal of Financial Economics 43, 153-194.

Gande, Amar, Manju Puri, and Anthony Saunders, 1999, Bank entry, competition and the market for corporate securities underwriting, Journal of Financial Economics 54, 165-195.

Gande, Amar, Manju Puri, Anthony Saunders, and Ingo Walter, 1997, Bank underwriting of debt securities: Modern evidence, Review of Financial Studies 10, 1175-1202.

Graham, John, 1999, Herding among investment newsletters: Theory and evidence, Journal of Finance 54, 237-268.

Heckman, James J., 1979, Sample selection bias as a specification error, Econometrica 47, 153-162.

Hong, Harrison, and Jeffrey D. Kubik, 2003, Analyzing the analysts: Career concerns and biased earnings forecasts, Journal of Finance 58, 313-351.

Hong, Harrison, Jeffrey D. Kubik, and Amit Solomon, 2000, Security analysts' career concerns and the herding of earnings forecasts, RAND Journal of Economics 31, 121-144.

James, Christopher M., 1992, Relationship-specific assets and the pricing of underwriter services, Journal of Finance 47, 1865-1885.

Krigman, Laurie, Wayne H. Shaw, and Kent L. Womack, 2001, Why do firms switch underwriters? Journal of Financial Economics 60, 245-284.

Lin, Hsiou-wei, and Maureen F. McNichols, 1998, Underwriting relationships, analysts' earnings forecasts and investment recommendations, Journal of Accounting and Economics 25, 101-127.

Livingston Miles B., and Robert Miller, 2000, Investment banker reputation and the underwriting of nonconvertible debt, Financial Management 29, 21-34.

Ljungqvist, Alexander, and William J. Wilhelm, 2003, IPO pricing in the dot-com bubble, Journal of Finance 58, 723-752.

Ljungqvist, Alexander, Felicia Marston, and William J. Wilhelm, 2003, Investment-banking relationships and strategic research coverage, unpublished working paper, New York University.

Maddala, G.S., 1983, Limited-Dependent and Qualitative Variables in Econometrics (Cambridge, Cambridge University Press).

Megginson, William L., and Kathleen A. Weiss, 1991, Venture capitalist certification in initial public offerings, Journal of Finance 46, 879-903.

Michaely, Roni, and Kent L. Womack, 1999, Conflict of interest and the credibility of underwriter analyst recommendations, Review of Financial Studies 12, 653-686.

Murphy, Kevin M., and Robert H. Topel, 1985, Estimation and inference in two-step econometric models, Journal of Business and Economic Statistics 13, 370-379. 
Petersen, Mitchell A., and Raghuram G. Rajan, 1994, The benefits of lending relationships:

Evidence from small business data, Journal of Finance 49, 3-37.

Petersen, Mitchell A., and Raghuram G. Rajan, 1995, The effect of credit market competition on lending relationships, Quarterly Journal of Economics 110, 407-443.

Roten, Ivan C., and Donald J. Mullineaux, 2003, Debt underwriting by commercial bank-affiliated firms and investment banks: More evidence, Journal of Banking and Finance, forthcoming.

Smith, Richard J., and Richard W. Blundell, 1986, An exogeneity test for a simultaneous equation Tobit model with an application to labor supply, Econometrica 54, 679-686.

Staiger, Douglas, and James H. Stock, 1997, Instrumental variables regression with weak instruments, Econometrica 65, 557-586.

Stickel, Scott E., 1990, Predicting individual analyst earnings forecasts, Journal of Accounting Research $28,409-417$.

Van de Ven, W.P.M.M., and B.M.S. Van Pragg, 1981, The demand for deductibles in private health insurance: A probit model with sample selection, Journal of Econometrics 17, 229-252.

Yasuda, Ayako, 2003, Do bank-firm relationships affect bank competition in the corporate bond underwriting market? Unpublished working paper, The Wharton School. 


\section{Figure 1. Principal bank mergers, 1988-2002.}

The figure presents a time line of the principal merger and acquisition events involving sample banks over the period 1988 to June 2002. A vertical line indicates a merger of two banks. A dashed line indicates a sale or split-off of a bank. For estimation purposes, the sample includes all banks active as of June 2002 (see the right-hand side legend) as well as their predecessor banks. These are the banks considered in competition for a given deal at a given point in time, as long as they held Tier II authority to underwrite securities at that time. There is one exception. The two boutique investment banks acquired by Prudential Securities, Vector Securities and Volpe Brown Whelan, are not considered in competition for any deals due to their specialized nature and small size. Prudential withdrew from underwriting in Q4 2000. Following a merger, the new entity "inherits" the relationships of its predecessors. Following a sale or a split-off, the new entities "inherit" the relationships previously developed by the joint entity. We consider a bank merged on the first day of the month following the completion of the merger. From that day on, it competes in its merged form. Tier II authority involves separate approval for debt and equity underwriting. The approval dates (debt, equity) used for the sample commercial banks are as follows: BA securities (10/11/94, 10/11/94), BT Securities (1/1/93, 1/15/91), BankBoston (11/1/96, 11/1/96), CIBC Wood Gundy Securities (6/30/90, 1/15/91), Chase Securities (7/26/89, 6/15/94), Chemical Securities (6/30/93, -), Deutsche Bank (12/1/92, 12/1/92), JP Morgan Securities (1/1/89, 1/1/90), NationsBank (7/26/93, 7/26/93), SBC (1/3/95, -), UBS Securities (debt underwriting grand-fathered in throughout sample period, equity: 1/1/95), Citicorp (7/26/89, expected to receive equity approval as of 3/27/95 but not clear if received prior to merger with Traveler's).

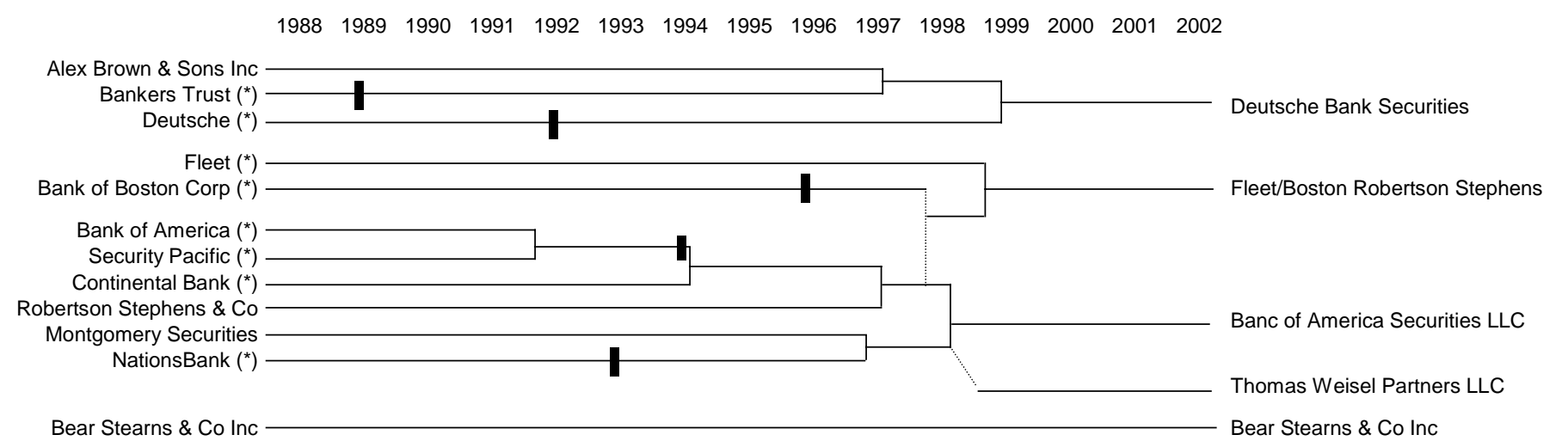

Manufacturers Hanover Bank $\left(^{*}\right)$ Chemical Bank $\left(^{*}\right)$

Chase Manhattan $\left(^{*}\right)$ Hambrecht \& Quist JP Morgan (*)

CIBC Wood Gundy Securities $\left({ }^{*}\right)$ Oppenheimer \& Co Inc

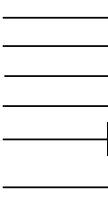

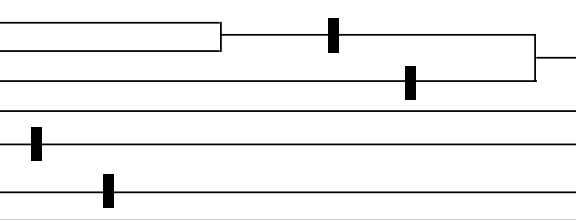

Bear Stearns \& Co Inc

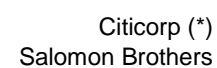
Salomon Brothers Smith Barney Inc Schroders

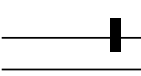

$$
1
$$

Cowen Societe Generale $\left(^{*}\right)$
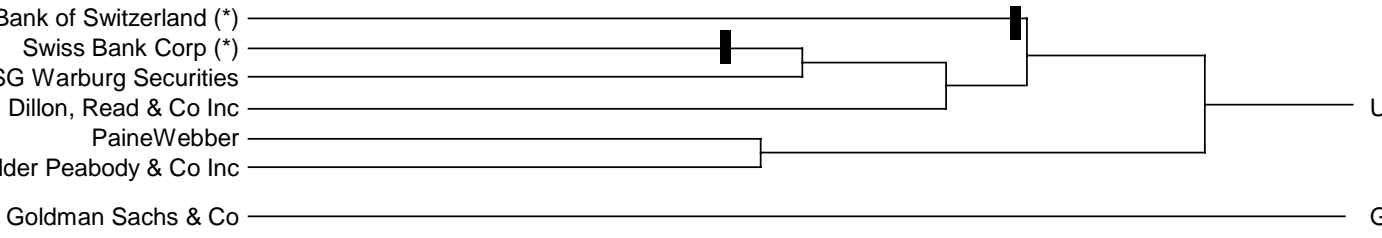$$
\text { (n) }
$$

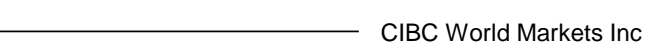

Salomon Smith Barney

UBS Warburg

Goldman Sachs \& Co

Lehman Brothers

Merrill Lynch \& Co Inc

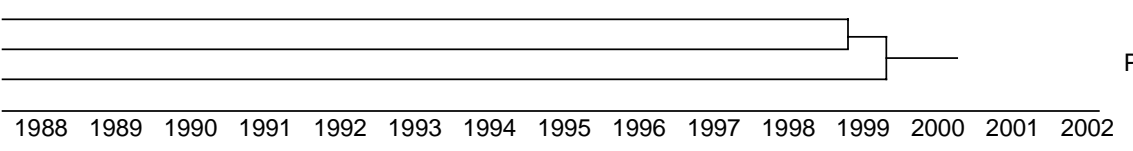

Prudential Volpe 


\section{Table 1. The Sample of Capital Raising Transactions.}

The total sample includes the universe of 36,173 capital raising transactions between January 1, 1988 and June 30,2002 reported by Securities Data Corporation excluding transactions by issuers classified as SIC 6000-6999 (financial institutions etc) and SIC 9000-9999 (government agencies etc). We use this sample to generate a variety of variables, including prior relationships between issuers and banks. Many issuers are related to each other so we form "corporate families" on the basis of SDC's "ultimate parent CUSIP" identifier. I/B/E/S data is available only from late 1993, so for the estimation of our econometric model we focus on a sub-sample of deals carried out between December 1, 1993 and June 30, 2002. We also exclude a) any issuer or family of issuers who never hired any of our "sample banks" for a capital raising transaction between 1988 and June 2002 (sample banks are identified in Table 2); and b) purely-foreign issuers or families of issuers (though we do include corporate families that have at least one U.S. member). The resulting estimation period sub-sample is shown in the final two columns.

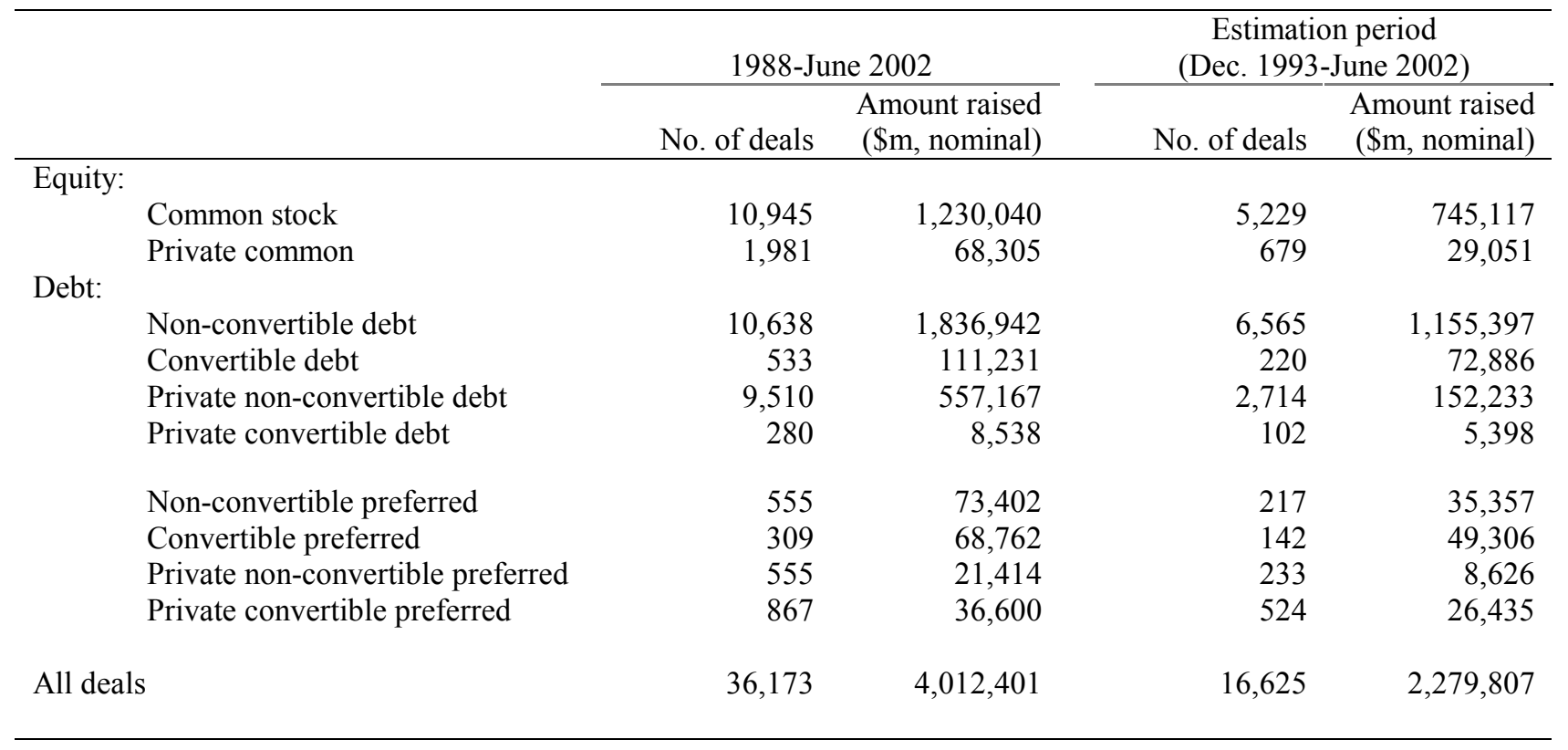


Table 2. The Bank Sample.

The table summarizes the market share captured by the 16 sample banks for the 36,173 sample transactions taking place during the January 1, 1988 through June 30, 2002 sample period. The bank sample comprises the 16 most-active underwriters judged by proceeds raised in both debt and equity offerings during 2000-2002. Market share is determined by assigning to the lead underwriter $100 \%$ of the nominal amount raised. (When there are co-leaders in a transaction, they share equally for the purposes of calculating market share). Many of the 16 banks represent the outcome of one or more mergers or acquisitions during the sample period. In such cases, the surviving bank listed below "inherits" the market share of its predecessors (listed in Figure 1).

\begin{tabular}{|c|c|c|c|c|c|c|}
\hline & \multicolumn{2}{|c|}{ Equity deals } & \multicolumn{2}{|c|}{ Debt deals } & \multicolumn{2}{|c|}{ All deals } \\
\hline & $\begin{array}{r}\text { Market } \\
\text { share (\%) }\end{array}$ & $\begin{array}{r}\text { Amount } \\
\text { raised }(\$ \mathrm{~m}, \\
\text { nominal })\end{array}$ & $\begin{array}{r}\text { Market } \\
\text { share }(\%)\end{array}$ & $\begin{array}{r}\text { Amount } \\
\text { raised }(\$ \mathrm{~m}, \\
\text { nominal) }\end{array}$ & $\begin{array}{r}\text { Market } \\
\text { share }(\%)\end{array}$ & $\begin{array}{r}\text { Amount } \\
\text { raised }(\$ \mathrm{~m} \text {, } \\
\text { nominal) }\end{array}$ \\
\hline Banc of America Securities LLC & 3.0 & 39,386 & 5.0 & 135,634 & 4.4 & 175,020 \\
\hline Bear Stearns \& Co Inc & 2.0 & 26,154 & 1.6 & 43,052 & 1.7 & 69,207 \\
\hline CIBC World Markets Inc & 0.8 & 10,264 & 0.3 & 7,036 & 0.4 & 17,299 \\
\hline Credit Suisse First Boston & 14.0 & 181,579 & 10.9 & 297,165 & 11.9 & 478,744 \\
\hline Deutsche Banc Securities & 4.2 & 54,185 & 2.2 & 60,744 & 2.9 & 114,930 \\
\hline Fleet Boston (Robertson Stephens) & 1.0 & 13,299 & 0.1 & 4,069 & 0.4 & 17,368 \\
\hline Goldman Sachs \& Co & 17.5 & 227,333 & 13.7 & 371,736 & 14.9 & 599,069 \\
\hline JP Morgan Chase & 4.5 & 58,730 & 9.7 & 264,421 & 8.1 & 323,150 \\
\hline Lehman Brothers & 5.0 & 65,413 & 6.5 & 175,650 & 6.0 & 241,063 \\
\hline Merrill Lynch \& Co Inc & 11.5 & 148,982 & 13.5 & 365,412 & 12.8 & 514,394 \\
\hline Morgan Stanley Dean Witter & 12.4 & 161,265 & 10.8 & 293,156 & 11.3 & 454,421 \\
\hline Prudential Volpe Technology Group & 0.8 & 10,340 & 0.3 & 8,918 & 0.5 & 19,258 \\
\hline SG Cowen Securities Corp & 0.6 & 8,038 & 0.1 & 2,211 & 0.3 & 10,248 \\
\hline Salomon Smith Barney & 8.7 & 113,432 & 14.4 & 389,678 & 12.5 & 503,110 \\
\hline Thomas Weisel Partners LLC & 0.2 & 2,119 & 0.0 & 25 & 0.1 & 2,144 \\
\hline UBS Warburg & 4.7 & 60,459 & 3.9 & 105,557 & 4.1 & 166,015 \\
\hline All 16 sample banks (and predecessors) & 91.0 & $1,180,977$ & 93.0 & $2,524,463$ & 92.3 & $3,705,440$ \\
\hline
\end{tabular}


Table 3. Bank-issuer Relationships and Bank Characteristics.

The dataset consists of 16,625 deals. The unit of observation is a bank-deal pair. Occasionally, banks co-lead a deal, so there are a total of 18,031 bankdeal pairs in the column headed "winning banks". The column headed "losing banks" refers to bank-deal pairs involving banks that were eligible to compete for but did not win a given deal. On average, there were 24.3 banks treated as competing for every deal. For each bank-deal pair, we report measures of the banks' prior relationships with the issuers, their shares of the equity, debt, and corporate loan markets, the number of "all-star" analyst teams they had according to the most recent Institutional Investor poll before the deal, the fraction of the issuer's industry covered by their analysts (aggregated into the 48 Fama-French (1997) industry groups), the extent of bank equity ownership in issuing firms (based on 13f filings as of the quarterend preceding the deal), and the fraction of commercial banks in each group. These are broken down by equity and debt, and by whether the bank's analyst covered the issuers stock in the prior 730 days. The final column shows tests of the null that the means and fractions for winning and losing banks are equal Though not shown, comparing coverage and no-coverage, all means and fractions are significantly different with one exception (the fraction of commercial banks among banks winning equity deals).

\begin{tabular}{|c|c|c|c|c|c|c|c|}
\hline & \multicolumn{3}{|c|}{ Winning banks } & \multicolumn{3}{|c|}{ Losing banks } & \multirow{2}{*}{$\begin{array}{r}\text { test: } \\
\text { winner } \\
\text { vs loser }\end{array}$} \\
\hline & mean & st.dev. & median & mean & st.dev. & median & \\
\hline Panel A: Equity - Coverage & $\mathrm{N}=1,924$ & & & $\mathrm{~N}=9,826$ & & & \\
\hline bank's share of issuer's equity deals over the prior 5 years (\%) & 47.4 & 47.3 & 39.3 & 6.4 & 22.5 & 0.0 & 58.4 \\
\hline bank's share of issuer's debt deals over the prior 5 years (\%) & 8.9 & 25.7 & 0.0 & 3.0 & 14.0 & 0.0 & 14.5 \\
\hline bank's share of issuer's loans over the prior 5 years $(\%)$ & 2.6 & 11.4 & 0.0 & 1.3 & 7.5 & 0.0 & 6.3 \\
\hline bank’s equity market share prior calendar year (\%) & 6.9 & 5.7 & 5.3 & 4.9 & 5.0 & 3.2 & 15.6 \\
\hline bank's debt market share prior calendar year $(\%)$ & 6.5 & 5.6 & 6.1 & 4.9 & 5.3 & 2.4 & 11.6 \\
\hline bank's loan market share prior calendar year (\%) & 1.8 & 3.3 & 0.5 & 2.0 & 3.8 & 0.4 & -2.2 \\
\hline bank's number of Institutional Investor "all-star" equity analysts & 26.5 & 19.0 & 30.0 & 21.7 & 17.9 & 19.0 & 10.7 \\
\hline fraction of issuer's Fama-French industry covered by bank (\%) & 22.6 & 11.3 & & 22.2 & 11.6 & & 0.5 \\
\hline fraction with bank stake in issuer's equity (\%) & 53.8 & 49.9 & & 54.7 & 49.8 & & -0.7 \\
\hline fraction commercial banks (\%) & 17.9 & 38.4 & & 23.5 & 42.4 & & -5.4 \\
\hline Panel B: Equity - No coverage & $\mathrm{N}=4,248$ & & & $\mathrm{~N}=127,023$ & & & \\
\hline bank's share of issuer's equity deals over the prior 5 years (\%) & 8.3 & 26.4 & 0.0 & 0.4 & 5.6 & 0.0 & 70.5 \\
\hline bank's share of issuer's debt deals over the prior 5 years (\%) & 4.7 & 20.0 & 0.0 & 0.4 & 5.5 & 0.0 & 43.0 \\
\hline bank's share of issuer's loans over the prior 5 years $(\%)$ & 1.2 & 8.4 & 0.0 & 0.6 & 6.1 & 0.0 & 6.4 \\
\hline bank's equity market share prior calendar year (\%) & 5.3 & 5.7 & 3.0 & 3.5 & 4.8 & 1.4 & 23.0 \\
\hline bank's debt market share prior calendar year $(\%)$ & 5.1 & 5.7 & 2.1 & 3.7 & 4.8 & 1.3 & 18.6 \\
\hline bank's loan market share prior calendar year (\%) & 1.5 & 3.0 & 0.1 & 2.1 & 3.6 & 0.3 & -11.4 \\
\hline bank's number of Institutional Investor "all-star" equity analysts & 20.1 & 19.8 & 15.0 & 14.9 & 16.7 & 9.0 & 20.0 \\
\hline fraction of issuer's Fama-French industry covered by bank (\%) & 14.5 & 12.2 & & 11.5 & 10.1 & & 5.9 \\
\hline fraction with bank stake in issuer's equity $(\%)$ & 17.3 & 37.8 & & 13.2 & 33.8 & & 7.7 \\
\hline fraction commercial banks $(\%)$ & 17.6 & 38.1 & & 30.2 & 45.9 & & -17.7 \\
\hline Panel C: Debt - Coverage & $\mathrm{N}=4,263$ & & & $\mathrm{~N}=54,036$ & & & \\
\hline bank's share of issuer's equity deals over the prior 5 years (\%) & 13.3 & 31.9 & 0.0 & 3.0 & 15.6 & 0.0 & 37.4 \\
\hline bank's share of issuer's debt deals over the prior 5 years (\%) & 26.2 & 31.0 & 15.0 & 4.9 & 13.6 & 0.0 & 86.2 \\
\hline bank's share of issuer's loans over the prior 5 years (\%) & 4.2 & 12.3 & 0.0 & 1.1 & 5.7 & 0.0 & 30.1 \\
\hline bank’s equity market share prior calendar year (\%) & 8.9 & 5.7 & 7.2 & 5.5 & 5.4 & 3.5 & 39.4 \\
\hline bank's debt market share prior calendar year (\%) & 10.0 & 4.6 & 10.7 & 5.4 & 5.2 & 3.6 & 55.8 \\
\hline bank's loan market share prior calendar year $(\%)$ & 2.5 & 4.1 & 0.6 & 1.5 & 2.9 & 0.3 & 22.0 \\
\hline bank's number of Institutional Investor "all-star" debt analysts & 16.7 & 10.2 & 17.0 & 11.1 & 10.6 & 9.0 & 33.4 \\
\hline fraction of issuer's Fama-French industry covered by bank (\%) & 26.3 & 13.0 & & 24.6 & 12.9 & & 2.4 \\
\hline fraction with bank stake in issuer's equity $(\%)$ & 68.3 & 46.5 & & 67.2 & 46.9 & & 1.5 \\
\hline fraction commercial banks (\%) & 21.9 & 41.3 & & 17.8 & 38.2 & & 6.7 \\
\hline Panel D: Debt - No coverage & $\mathrm{N}=7,596$ & & & $\mathrm{~N}=194,379$ & & & \\
\hline bank's share of issuer's equity deals over the prior 5 years (\%) & 4.2 & 19.0 & 0.0 & 0.6 & 6.9 & 0.0 & 39.8 \\
\hline bank's share of issuer's debt deals over the prior 5 years (\%) & 18.0 & 31.0 & 0.0 & 1.3 & 8.1 & 0.0 & 144.1 \\
\hline bank's share of issuer's loans over the prior 5 years (\%) & 7.2 & 20.0 & 0.0 & 1.3 & 7.3 & 0.0 & 62.2 \\
\hline bank’s equity market share prior calendar year (\%) & 4.7 & 5.8 & 2.1 & 3.1 & 4.5 & 1.2 & 31.0 \\
\hline bank's debt market share prior calendar year $(\%)$ & 6.3 & 5.7 & 4.4 & 3.2 & 4.5 & 1.2 & 56.9 \\
\hline bank's loan market share prior calendar year (\%) & 4.4 & 5.4 & 1.4 & 2.6 & 3.9 & 0.8 & 38.3 \\
\hline bank's number of Institutional Investor "all-star" debt analysts & 9.8 & 11.3 & 5.0 & 6.3 & 9.1 & 2.0 & 32.5 \\
\hline fraction of issuer's Fama-French industry covered by bank (\%) & 11.5 & 13.5 & & 10.7 & 11.8 & & 2.1 \\
\hline fraction with bank stake in issuer's equity (\%) & 33.4 & 47.2 & & 32.7 & 46.9 & & 1.3 \\
\hline fraction commercial banks (\%) & 48.4 & 50.0 & & 37.5 & 48.4 & & 19.2 \\
\hline
\end{tabular}


Table 4. Descriptive Statistics: Issuer and Deal Characteristics.

The dataset contains 16,625 deals by 6,821 unique companies and 5,472 unique corporate families. 10,717 of the 16,625 deals involve issuers that are covered by at least one sample bank in $\mathrm{I} / \mathrm{B} / \mathrm{E} / \mathrm{S}$ in the 730 days prior to the deal. All currency amounts are in nominal terms.

\begin{tabular}{|c|c|c|c|c|c|c|c|}
\hline & \multicolumn{3}{|c|}{ Coverage } & \multicolumn{3}{|c|}{ No coverage } & \multirow{2}{*}{$\begin{array}{r}\text { test } \mathrm{o} \\
\text { difference } \\
\text { in means } \\
\text { fraction }\end{array}$} \\
\hline & mean & st.dev. & median & mean & st.dev. & median & \\
\hline Panel A: Equity deals & $\mathrm{N}=2,837$ & & & $\mathrm{~N}=3,071$ & & & \\
\hline deal size (in $\$ \mathrm{~m}$ ) & 183.4 & 415.9 & 86.4 & 82.7 & 190.5 & 43.8 & 12.1 \\
\hline issuer's equity proceeds prior 5 years (in $\$ \mathrm{~m}$ ) & 175.7 & 516.9 & 53.6 & 14.9 & 130.8 & 0.0 & 16.7 \\
\hline issuer's debt proceeds prior 5 years (in $\$ \mathrm{~m}$ ) & 269.1 & 989.8 & 0.0 & 39.2 & 544.4 & 0.0 & 11.2 \\
\hline time since IPO (in years) & 9.4 & 12.4 & 4.7 & 1.6 & 6.1 & 0.0 & 30.1 \\
\hline fraction not listed (\%) & 0.4 & & & 7.9 & & & -14.2 \\
\hline fraction U.S. company (\%) & 98.4 & & & 98.9 & & & -1.7 \\
\hline Panel B: Debt deals & $\mathrm{N}=7,880$ & & & $\mathrm{~N}=2,837$ & & & \\
\hline deal size (in \$m) & 164.6 & 266.1 & 90.0 & 73.5 & 114.8 & 32.0 & 17.7 \\
\hline issuer's equity proceeds prior 5 years (in $\$ \mathrm{~m}$ ) & 263.0 & 828.1 & 0.0 & 52.8 & 345.7 & 0.0 & 13.1 \\
\hline issuer's debt proceeds prior 5 years (in \$m) & $2,511.8$ & $5,433.4$ & 799.1 & 259.5 & 1413.0 & 0.0 & 21.8 \\
\hline time since IPO (in years) & 27.8 & 18.3 & 28.4 & 4.8 & 12.1 & 0.0 & 59.6 \\
\hline fraction not listed (\%) & 2.2 & & & 71.3 & & & -78.3 \\
\hline fraction U.S. company (\%) & 98.3 & & & 94.1 & & & 11.4 \\
\hline
\end{tabular}




\section{Table 5. Recommendations and Analyst Characteristics.}

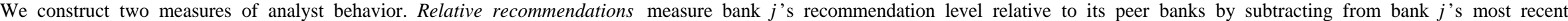

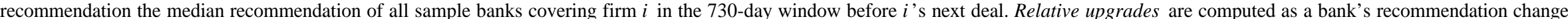

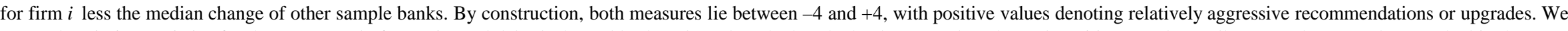

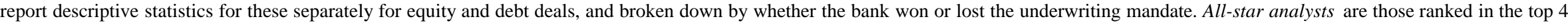

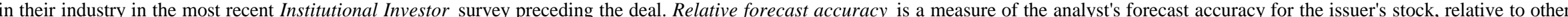

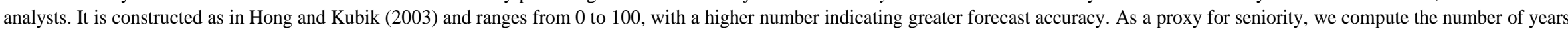
since the analyst first appeared in the I/B/E/S database. The last column provides $t$-tests of differences in means/fractions.

\begin{tabular}{|c|c|c|c|c|c|c|c|c|c|c|c|c|c|}
\hline & \multicolumn{4}{|c|}{ All banks } & \multicolumn{4}{|c|}{ Winning banks } & \multicolumn{4}{|c|}{ Losing banks } & \multirow{2}{*}{$\begin{array}{r}\text { test } \\
\text { winner } \\
\text { vs. loser }\end{array}$} \\
\hline & No. obs & mean & st.dev. & median & No. obs & mean & st.dev. & median & No. obs & mean & st.dev. & median & \\
\hline \multicolumn{14}{|l|}{ Panel A: Equity deals } \\
\hline relative recommendation & 11,750 & 0.011 & 0.659 & 0.000 & 1,924 & 0.172 & 0.518 & 0.000 & 9,826 & -0.021 & 0.678 & 0.000 & 11.8 \\
\hline relative upgrade & 11,750 & 0.081 & 0.737 & 0.000 & 1,924 & 0.096 & 0.647 & 0.000 & 9,826 & 0.078 & 0.753 & 0.000 & 1.0 \\
\hline fraction of issuers covered by all-star analysts (\%) & 11,750 & 29.1 & & & 1,924 & 36.2 & & & 9,826 & 27.7 & & & 7.5 \\
\hline relative forecast accuracy & 10,881 & 51.7 & 10.5 & 52.3 & 1,827 & 51.9 & 10.6 & 52.7 & 9,054 & 51.7 & 10.4 & 52.2 & 0.7 \\
\hline analyst's seniority (years in I/B/E/S database) & 11,323 & 6.5 & 4.8 & 5.6 & 1,880 & 6.9 & 4.7 & 6.1 & 9,443 & 6.4 & 4.8 & 5.4 & 4.1 \\
\hline \multicolumn{14}{|l|}{ Panel B: Debt deals } \\
\hline relative recommendation & 58,299 & 0.033 & 0.767 & 0.000 & 4,263 & 0.186 & 0.686 & 0.000 & 54,036 & 0.021 & 0.772 & 0.000 & 13.6 \\
\hline relative upgrade & 58,299 & 0.076 & 0.804 & 0.000 & 4,263 & 0.133 & 0.778 & 0.000 & 54,036 & 0.072 & 0.806 & 0.000 & 4.8 \\
\hline fraction of issuers covered by all-star analysts (\%) & 58,299 & 37.4 & & & 4,263 & 44.0 & & & 54,036 & 36.9 & & & 9.3 \\
\hline relative forecast accuracy & 54,914 & 52.3 & 9.0 & 53.0 & 4,026 & 52.8 & 8.6 & 53.0 & 50,888 & 52.2 & 9.1 & 53.0 & 3.8 \\
\hline analyst's seniority (years in $\mathrm{I} / \mathrm{B} / \mathrm{E} / \mathrm{S}$ database) & 56,786 & 7.2 & 4.9 & 6.4 & 4,151 & 7.5 & 5.0 & 6.9 & 52,635 & 7.2 & 4.9 & 6.4 & 4.7 \\
\hline
\end{tabular}




\section{Table 6. Analyst Behavior.}

The dependent variable is analyst behavior as measured by relative recommendations and relative upgrades. This is observed only when the bank covers the stock, so we estimate Heckman (1979) selection models using MLE. The table reports estimation results in structural form. The reduced forms used to generate instruments for the models in Tables 7 and 8 include also the exogenous variables from the lead-bank equation and are not shown. The relative upgrade models include a dummy equal to one if the previous recommendation was a strong buy; the coefficients, which are negative and significant, are not shown. The bubble dummy equals 1 for deals in 1999 and 2000. Analyst characteristics (relative forecast accuracy and seniority) are defined as in Table 5. To proxy for the size of potential rewards for liquidating reputation capital, we calculate the percentage difference in market-wide proceeds raised during the current quarter and a five-year quarterly moving average. Results are robust to using shorter windows. Intercepts are not shown. Standard errors are shown in italics. We use ${ }^{* * *},{ }^{* *},{ }^{*}$ and $\dagger$ to denote significance at the $0.1 \%, 1 \%, 5 \%$, and $10 \%$ level (two-sided), respectively. The number of observations where the bank provides research coverage is 10,870 in the equity model and 54,896 in the debt model.

\begin{tabular}{|c|c|c|c|c|}
\hline \multirow[b]{2}{*}{ Relative... } & \multicolumn{2}{|c|}{ Equity } & \multicolumn{2}{|c|}{ Debt } \\
\hline & recomm. & upgrades & recomm. & upgrades \\
\hline \multicolumn{5}{|l|}{ Bank-issuer relationships } \\
\hline \multirow[t]{2}{*}{ bank's share of issuer's debt deals prior 5 years } & $0.157^{* * *}$ & 0.025 & $0.256^{* * *}$ & $0.092^{* * *}$ \\
\hline & 0.038 & 0.042 & 0.021 & 0.022 \\
\hline \multirow[t]{2}{*}{ bank's share of issuer's equity deals prior 5 years } & $0.150^{* * *}$ & -0.018 & $0.136^{* * *}$ & $0.136^{* * *}$ \\
\hline & 0.027 & 0.030 & 0.019 & 0.020 \\
\hline \multirow[t]{2}{*}{ bank's share of issuer's loans prior 5 years } & 0.093 & 0.125 & $0.540^{* * *}$ & $0.181^{* * *}$ \\
\hline & 0.080 & 0.088 & 0.056 & 0.057 \\
\hline \multirow[t]{2}{*}{$=1$ if bank owns equity in issuer } & $0.072^{* * *}$ & $0.058^{* * *}$ & $0.041^{* * *}$ & $0.041^{* * *}$ \\
\hline & 0.016 & 0.018 & 0.008 & 0.008 \\
\hline \multicolumn{5}{|l|}{ Bank and analyst characteristics } \\
\hline \multirow[t]{2}{*}{ bank's II rank (log number of ranked equity/debt analysts) } & 0.008 & $0.022^{* *}$ & $-0.014^{* * *}$ & $0.032^{* * *}$ \\
\hline & 0.007 & 0.008 & 0.003 & 0.004 \\
\hline \multirow[t]{2}{*}{ bank's equity market share prior calendar year } & $-0.981^{* * *}$ & -0.347 & $-0.982^{* * *}$ & $-0.399^{* * *}$ \\
\hline & 0.217 & 0.239 & 0.106 & 0.109 \\
\hline \multirow[t]{2}{*}{ bank's debt market share prior calendar year } & $0.754^{* * *}$ & -0.108 & $1.486^{* * *}$ & 0.064 \\
\hline & 0.248 & 0.273 & 0.130 & 0.134 \\
\hline \multirow[t]{2}{*}{ bank's loan market share prior calendar year } & 0.269 & $0.704^{* *}$ & $0.933^{* * *}$ & $1.324^{* * *}$ \\
\hline & 0.212 & 0.233 & 0.137 & 0.141 \\
\hline \multirow[t]{2}{*}{$=1$ if analyst is ranked "all-star" by Institutional Investor } & -0.003 & $-0.042^{*}$ & $0.038^{* * *}$ & $-0.035^{* * *}$ \\
\hline & 0.017 & 0.019 & 0.008 & 0.008 \\
\hline \multirow[t]{2}{*}{$\ldots x$ bubble dummy } & 0.020 & $0.065^{*}$ & $-0.031^{*}$ & $0.056^{* * *}$ \\
\hline & 0.027 & 0.030 & 0.014 & 0.015 \\
\hline \multirow[t]{2}{*}{ relative forecast accuracy } & $0.0013^{*}$ & 0.000 & $0.003^{* * *}$ & $0.002^{* * *}$ \\
\hline & 0.0006 & 0.001 & 0.0004 & 0.0004 \\
\hline \multirow[t]{2}{*}{ log analyst's seniority (in years) } & 0.008 & -0.001 & -0.002 & $0.013^{* *}$ \\
\hline & 0.009 & 0.010 & 0.005 & 0.005 \\
\hline \multirow[t]{2}{*}{ change in issue activity relative to 5 -yr moving average } & $-0.067^{\dagger}$ & -0.046 & $-0.056^{* *}$ & $-0.090^{* * *}$ \\
\hline & 0.036 & 0.040 & 0.019 & 0.020 \\
\hline \multirow[t]{2}{*}{$\ldots \mathrm{x}$ bank's market share } & 0.832 & 0.652 & $0.628^{*}$ & $0.922^{* * *}$ \\
\hline & 0.522 & 0.573 & 0.257 & 0.264 \\
\hline \multicolumn{5}{|l|}{ Issuer characteristics } \\
\hline \multirow[t]{2}{*}{$\log \$$ deal size } & $-0.017^{* *}$ & $0.027^{* * *}$ & $-0.009^{* * *}$ & $0.015^{* * *}$ \\
\hline & 0.006 & 0.007 & 0.002 & 0.002 \\
\hline \multirow[t]{2}{*}{$\log$ issuer's $\$$ equity or debt proceeds prior 5 years } & 0.003 & $0.010^{* *}$ & $-0.006^{* * *}$ & $0.014^{* * *}$ \\
\hline & 0.003 & 0.003 & 0.002 & 0.002 \\
\hline \multicolumn{5}{|l|}{ Diagnostics } \\
\hline Wald test: all coefficients $=0\left(\chi^{2}\right)$ & $138.1^{* * *}$ & $467.8^{* * *}$ & $1,215.5^{* * *}$ & $4,167.2^{* * *}$ \\
\hline Heckman's $\lambda$ (probability of non-coverage) & 0.025 & $0.060^{* * *}$ & $0.028^{* *}$ & $0.138^{* * *}$ \\
\hline Likelihood ratio test of independent equations $(\rho=0)\left(\chi^{2}\right)$ & 1.8 & $8.2^{* *}$ & $9.0^{* *}$ & $191.0^{* * *}$ \\
\hline
\end{tabular}


Table 7. Lead Bank Choice, Equity Transactions.

We estimate the probability that a particular bank is chosen to lead-manage a particular equity deal using probit MLE with sample selection correction. Specification 1 uses relative recommendations and Specification 2 uses relative upgrades to model analyst behavior. These are instrumented from the models estimated in Table 6 and so treated as endogenous. Analyst behavior is observed only if the bank provides coverage, so we estimate the probability of winning a deal separately if the bank provides research coverage and if it does not. The dummies for mergers and staff arrivals/departures are coded 1 in the quarter of the event, and $1 / 2,1 / 3$, and $1 / 4$ in the next three quarters. Intercepts are not shown. Standard errors are shown in italics. Where necessary, they are based on the Murphy-Topel adjustment. We use ${ }^{* * *},{ }^{* *},{ }^{*}$ and $\dagger$ to denote significance at the $0.1 \%, 1 \%, 5 \%$, and $10 \%$ level (twosided), respectively. The columns headed "Test" show the significance of Wald tests comparing the coefficients in the coverage and no-coverage cases. The number of covered and non-covered observations is 10,870 and 131,271, respectively.

\begin{tabular}{|c|c|c|c|c|c|}
\hline & \multicolumn{2}{|c|}{ Coverage } & \multirow[b]{2}{*}{$\begin{array}{c}\text { No } \\
\text { coverage }\end{array}$} & \multicolumn{2}{|c|}{ Test } \\
\hline & Spec. 1 & Spec. 2 & & $\begin{array}{l}\text { rel. to } \\
\text { Spec. } 1\end{array}$ & $\begin{array}{c}\text { rel. to } \\
\text { Spec. } 2\end{array}$ \\
\hline \multicolumn{6}{|l|}{ Analyst behavior } \\
\hline \multirow[t]{2}{*}{ relative recommendations } & 1.504 & & & & \\
\hline & 0.946 & & & & \\
\hline \multirow[t]{2}{*}{ relative upgrades } & & $-0.549^{* * *}$ & & & \\
\hline & & 0.136 & & & \\
\hline \multicolumn{6}{|l|}{ Bank-issuer relationships } \\
\hline \multirow[t]{2}{*}{ bank's share of issuer's debt deals prior 5 years } & 0.360 & $0.604^{* * *}$ & $1.222^{* * *}$ & *** & $* * *$ \\
\hline & 0.226 & 0.093 & 0.060 & & \\
\hline \multirow[t]{2}{*}{ bank's share of issuer's equity deals prior 5 years } & $1.650^{* * *}$ & $1.863^{* * *}$ & $1.937^{* * *}$ & $* * *$ & \\
\hline & 0.317 & 0.113 & 0.057 & & \\
\hline \multirow[t]{2}{*}{ bank's share of issuer's loans prior 5 years } & $0.556^{*}$ & $0.773^{* * *}$ & $0.574^{* * *}$ & & * \\
\hline & 0.249 & 0.188 & 0.091 & & \\
\hline \multirow[t]{2}{*}{$=1$ if bank owns equity in issuer } & -0.036 & $0.096^{* * *}$ & $0.131^{* * *}$ & $* * *$ & \\
\hline & 0.202 & 0.084 & 0.025 & & \\
\hline \multirow[t]{2}{*}{ dummy: bank involved in merger } & $0.307^{\dagger}$ & 0.056 & $0.146^{* *}$ & *** & $\dagger$ \\
\hline & 0.167 & 0.103 & 0.048 & & \\
\hline \multirow[t]{2}{*}{ dummy: equity staff have departed } & -0.082 & -0.075 & $-0.101^{* *}$ & & \\
\hline & 0.111 & 0.094 & 0.049 & & \\
\hline \multirow[t]{2}{*}{ dummy: equity staff have arrived } & -0.055 & -0.052 & $0.179^{* * *}$ & *** & *** \\
\hline & 0.104 & 0.096 & 0.041 & & \\
\hline \multicolumn{6}{|l|}{ Bank characteristics } \\
\hline \multirow[t]{2}{*}{ bank's II rank (log number of ranked equity analysts) } & -0.012 & 0.004 & $-0.056^{* * *}$ & *** & *** \\
\hline & 0.033 & 0.020 & 0.007 & & \\
\hline \multirow[t]{2}{*}{$=1$ if analyst is ranked "all-star" by Institutional Investor } & $0.127^{* *}$ & $0.123^{* * *}$ & & & \\
\hline & 0.043 & 0.038 & & & \\
\hline \multirow[t]{2}{*}{ bank's equity market share prior calendar year } & $4.362^{* * *}$ & $2.883^{* * *}$ & $2.032^{* * *}$ & $* * *$ & $* * *$ \\
\hline & 1.146 & 0.528 & 0.244 & & \\
\hline \multirow[t]{2}{*}{ bank's debt market share prior calendar year } & -0.727 & 0.526 & $1.342^{* * *}$ & *** & ** \\
\hline & 1.029 & 0.611 & 0.288 & & \\
\hline \multirow[t]{2}{*}{ bank's loan market share prior calendar year } & -1.066 & -0.236 & $-3.682^{* * *}$ & $* * *$ & $* * *$ \\
\hline & 0.658 & 0.599 & 0.273 & & \\
\hline \multicolumn{6}{|l|}{ Diagnostics } \\
\hline Wald test: all coefficients $=0\left(\chi^{2}\right)$ & $1,918^{* * *}$ & $1,916^{* * *}$ & $2,338^{* * *}$ & & \\
\hline Correlation of coverage and lead-bank equations $(\rho)$ & $0.286^{* * *}$ & $0.280^{* * *}$ & $0.267^{* * *}$ & & \\
\hline Likelihood ratio test of independent equations $(\rho=0)\left(\chi^{2}\right)$ & $47.9^{* * *}$ & $46.4^{* * *}$ & $38.9^{* * *}$ & & \\
\hline
\end{tabular}




\section{Table 8. Lead Bank Choice, Debt Transactions.}

We estimate the probability that a particular bank is chosen to lead-manage a particular debt deal using probit MLE with sample selection correction. Specification 1 uses relative recommendations and Specification 2 uses relative upgrades to model analyst behavior. These are instrumented from the models estimated in Table 6 and so treated as endogenous. Analyst behavior is observed only if the bank provides coverage, so we estimate the probability of winning a deal separately if the bank provides research coverage and if it does not. The dummies for mergers and staff arrivals/departures are coded 1 in the quarter of the event, and $1 / 2,1 / 3$, and $1 / 4$ in the next three quarters. Intercepts are not shown. Standard errors are shown in italics. Where necessary, they are based on the Murphy-Topel adjustment. We use ${ }^{* * *},{ }^{* *},{ }^{*}$ and $\dagger$ to denote significance at the $0.1 \%, 1 \%, 5 \%$, and $10 \%$ level (twosided), respectively. The columns headed "Test" show the significance of Wald tests comparing the coefficients in the coverage and no-coverage cases. The number of covered and non-covered observations is 54,896 and 201,975, respectively.

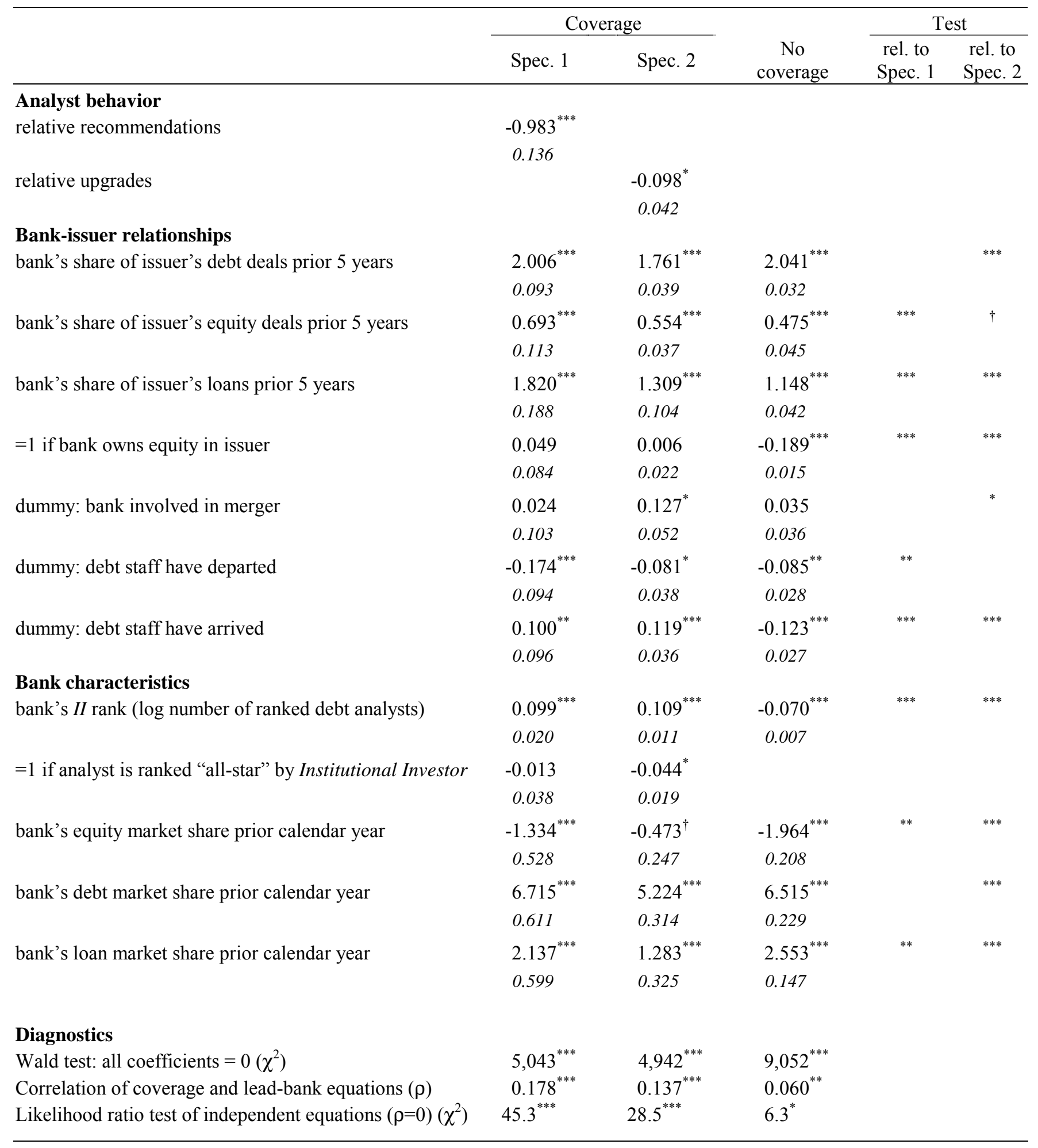


Table 9. Differences Over Time.

As in Tables 7 and 8 , we estimate the probability that a particular bank is chosen to lead-manage a particular deal using probit MLE with sample selection correction. Here, we partition the sample into two periods, 1993-1997 and 1998-2002. To model analyst behavior, we instrument relative recommendations and relative upgrades from auxiliary models similar to those reported in Table 6, but estimated within each sub-period. To conserve space, we report only the coefficients and Murphy-Topel corrected standard errors for the instrumented analyst behavior variables. We use ${ }^{* * *},{ }^{* *},{ }^{*}$ and $\dagger$ to denote significance at the $0.1 \%, 1 \%, 5 \%$, and $10 \%$ level (two-sided), respectively.

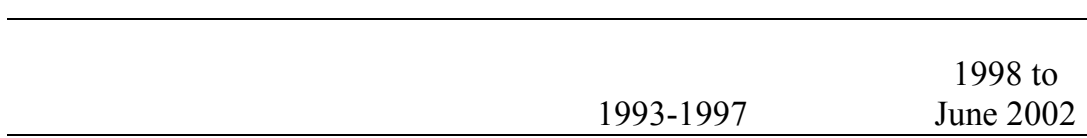

\section{Equity}

Relative upgrades

$\begin{array}{cc}-0.357^{*} & -0.635^{* *} \\ 0.157 & 0.223\end{array}$

Relative recommendations

$\begin{array}{ll}3.238 & 0.088 \\ 8.038 & 0.500\end{array}$

Debt

Relative upgrades

$\begin{array}{cc}-0.196^{* *} & -0.028 \\ 0.067 & 0.055\end{array}$

Relative recommendations

$\begin{array}{ll}-1.416^{* * *} & 2.212^{* * *} \\ 0.443 & 0.606\end{array}$

